\title{
Electoral Competitiveness, Tax Bargaining and Political Incentives in Developing Countries: Evidence from Political Budget Cycles Affecting Taxation
}

\author{
WILSON PRICHARD*
}

\begin{abstract}
Studies of political budget cycles in developing countries have generally sought to inform understanding of short-term fiscal dynamics, but can also offer unique insight into broader political dynamics in developing countries. This article correspondingly employs markedly improved data in order to study the impact of elections on tax collection, and draw broader lessons. It shows that while elections as a group have had no significant effect on tax collection, the subset of competitive elections has had a significant negative impact on pre-election tax collection; while this effect appears to be largest where incumbents are particularly unpopular. This provides powerful evidence that the impact of elections on political incentives in developing countries is conditioned by the existence of an electorally competitive opposition, while offering preliminary evidence that popular resistance to taxation by unpopular governments may be an important means by which taxpayers may generate pressure for improved governance.
\end{abstract}

A long-established research tradition explores the effects of elections on short-term fiscal policy making, widely dubbed 'political budget cycles'. Models of opportunistic budget cycles predict expanded public spending and reduced taxation in advance of elections, as governments seek to secure short-term political support among voters with short time horizons or limited information. ${ }^{1}$ The recent literature has, in turn, increasingly focused on the possibility of 'conditional political budget cycles', and a variety of studies have found that political budget cycles are more pronounced where democratic institutions, and broader checks and balances, are relatively weak - as is frequently the case in developing countries. ${ }^{2}$ These studies have argued that weak institutional environments have facilitated opportunistic efforts to employ short-term fiscal policy measures to secure political support, though often at the expense of the overall quality of economic management.

However, most studies of political budget cycles have continued to focus primarily on public expenditure, with comparatively limited, and inconclusive, research focused on the impacts of political budget cycles on taxation. This represents a significant oversight: the effects of elections on tax collection may be both more substantively important and reveal more about broader political dynamics in developing country democracies. Short-term increases in public spending are relatively easily financed through borrowing, and in many (though not all) cases

* Department of Political Science and School of Global Affairs, University of Toronto, and Institute of Development Studies, UK (email: wilson.prichard@utoronto.ca). Enormous thanks to Paola Salardi for invaluable support in shaping the analysis in the article, and to Mick Moore for very helpful comments about the framing of the article. Data replication sets available at https://dataverse.harvard.edu/dataverse/BJPolS and online appendices at http://dx.doi.org/doi:10.1017/S0007123415000757.

1 Drazen 2001.

2 de Haan and Klomp 2013. 
those spending increases can be curtailed following elections. By contrast, reductions in tax collection can only be achieved through either difficult-to-reverse reductions in rates, or by reducing the quality of tax enforcement, which has potentially negative consequences for long-term state building and accountability. ${ }^{3}$ Both possibilities imply significant direct costs to developing countries. As importantly, precisely because of these comparatively high costs, evidence that elections have shaped pre-election tax collection may offer broader insights into the political dynamics surrounding developing country elections.

Existing studies have generally viewed political budget cycles as evidence of institutional weakness. However, they may also hold broader insights into politics in developing countries. First, political budget cycles around taxation may be understood as positive evidence that elections are able to shift the incentives of political leaders, who are compelled to cut taxes in order to respond to voters' concerns. Irrespective of whether this is desirable in technocratic terms, it stands in contrast to continuing concerns that elections in many developing countries may be relatively ineffective at shaping the incentives of political leaders owing to, among other factors, electoral fraud and weak opposition parties. ${ }^{4}$ Of particular interest is the possibility that competitive elections may have significantly stronger effects on political incentives than less-contested elections. Secondly, declining tax collection prior to elections may not only reflect a purposeful strategy by political leaders to purchase political support, but may be evidence of the declining capacity of unpopular governments to collect taxes in the run-up to elections. This builds on recent case study research finding that taxpayers and civil servants have sometimes expanded tax resistance, or at least passive non-compliance, in the lead up to elections, in part as an indirect form of 'tax bargaining' aimed at generating pressure for broader governance improvements. ${ }^{5}$

This article correspondingly employs a new government revenue dataset to conduct the most in-depth study to date of the impact of developing country elections on pre-election tax collection. In contrast to recent work by Ehrhart, ${ }^{6}$ it presents evidence that when all elections are pooled together they have no statistically significant impact on tax collection. This is not necessarily surprising: several earlier studies, though focused primarily on expenditure, have revealed no short-term impact of elections on taxation, reflecting the comparative difficulty and cost of reducing tax collection. ${ }^{7}$ However, the subsequent analysis reveals that while elections in general have not had a negative impact on tax collection, competitive elections - initially defined as elections in which the opposition wins at least 40 per cent of electoral seats - have had a significant and substantial negative impact on pre-election tax collection. This relationship appears to be robust: it holds true across both fixed-effects and System-GMM estimators, and is robust to changes in the model, sample, time period, definition of competitiveness and level of government revenue data employed. In turn, we find strongly suggestive evidence that decreases in tax collection have been particularly significant prior to elections that have been competitive and in which the incumbent has been replaced, suggesting that unpopular governments have witnessed particularly large pre-election declines in tax collection.

While these findings are important to our understanding of political budget cycles specifically, they also appear to offer broader insights. The first is comparatively intuitive: that elections have a greater effect on the political incentives of governments when they are more competitive. It is a foundational feature of democratic theory that the incentives generated

${ }^{3}$ Brautigam et al. 2008.

${ }^{4}$ Rakner and van de Walle 2009; Schedler 2002; van de Walle 2003.

5 Prichard 2015.

${ }^{6}$ Ehrhart 2013.

${ }^{7}$ Brender and Drazen 2005. There is similarly no consistent evidence of an effect when the focus is exclusively on contested multiparty elections, on the first elections in new democracies, or on 'free and fair' elections. 
by elections will be substantially stronger when the incumbent government faces a genuine threat of losing office. ${ }^{8}$ However, the relationship between electoral competitiveness and political incentives is difficult to test empirically, ${ }^{9}$ while most quantitative studies of elections in developing countries have continued to focus on all contested elections, with much more limited attention paid to substantive electoral competitiveness. ${ }^{10}$ Against this background, this article provides among the clearest existing illustrations of the importance of electoral competitiveness in shaping the strength of the incentives generated by elections.

The second message relates to the mechanisms driving pre-election declines in tax collection, and what those mechanisms may tell us about state-society relations. As noted above, declining tax revenue prior to elections may be explained by a conscious government strategy to reduce collection, but may also result from unpopular incumbent governments experiencing declining capacity to collect revenue prior to elections amidst expanded non-compliance and popular resistance. The results here support the importance of both strategy and capacity, as tax collection appears to have declined particularly sharply where incumbents have been most unpopular. This has potentially important implications. Declining collection where governments are unpopular is not only consistent with models of 'quasi-voluntary' tax compliance, but suggests that popular resistance to taxation may be an important channel by which dissatisfied populations have weakened unpopular governments and generated long-term pressure for greater responsiveness and accountability. ${ }^{11}$

The article proceeds as follows. The next section provides a brief review of the literature. Afterwards, the research questions are specified and the data reviewed. Then the empirical strategy is described, followed by the key results. The final sections present robustness tests, discuss the key findings and conclude.

\section{TAXATION AND POLITICAL BUDGET CYCLES IN DEVELOPING COUNTRIES}

Researchers have long been interested in the possibility that elections may lead governments to alter patterns of pre-election expenditure and taxation in an effort to secure electoral support. ${ }^{12}$ The intuition behind opportunistic political budget cycles is straightforward: if voters are relatively short-sighted, or have limited information, then short-term increases in public spending, or decreases in tax collection, could be effective strategies for increasing government popularity. ${ }^{13}$

More recent research has turned attention to the possibility of 'conditional political budget cycles', with the existence or absence of political budget cycles dependent on particular features of the institutional environment, or particular features of different elections. ${ }^{14}$ This literature has argued that political budget cycles are more common where checks and balances are weak, and experience with democracy is more limited, as such weak institutional environments offer greater scope for politicians to secure support though short-term policy measures. Consistent with these arguments, most studies have found that political budget cycles are more pronounced in the developing world. ${ }^{15}$

8 Kitschelt and Wilkinson 2007.

9 Gordon and Huber 2007.

${ }^{10}$ Harding and Stasavage 2014; Stasavage 2005.

11 Prichard 2015.

12 Drazen 2001.

13 Norhaus 1975; Persson and Tabellini 1990; Rogoff and Sibert 1988.

14 de Haan and Klomp 2013.

15 Brender and Drazen 2005; de Haan and Klomp 2013; Ehrhart 2013; Shi and Svensson 2006. 
Several studies have also explored whether the characteristics of elections themselves may condition their impact on fiscal variables. The most interesting of these possibilities surrounds electoral competitiveness. It is a foundational feature of democratic theory that elections will have a greater impact on political incentives where they are more competitive. According to this logic, political budget cycles should be larger where elections are more competitive, but this relationship has only been very imperfectly tested in the existing literature on developing countries. The most important study is that of Block, Ferree and Singh, ${ }^{16}$ who report evidence that competitive elections have, as expected, generated larger political budget cycles. This is consistent with Brender and Drazen, who write that, 'In our view, if the political budget cycle reflects the manipulation of fiscal policy to improve an incumbent's re-election chances, then it only makes sense in countries in which elections are competitive. ${ }^{17}$

However, these studies adopt a very limited definition of 'competitiveness' that is focused exclusively on whether a country has multiparty competition. Yet the simple existence of multiparty competition may not imply genuine 'competitiveness' if the margin of victory is so large that the incumbent nonetheless faces little or no threat of losing power. Why would a government take the costly step of increasing short-term expenditure, or reducing tax collection, if its electoral victory is already essentially assured? Recent studies from Europe ${ }^{18}$ have correspondingly adopted a more demanding standard, asking whether political budget cycles are larger when the incumbent government faces a more substantive challenge to its hold on power, as measured by the margin of victory. This offers a more robust picture of the extent to which substantive electoral competitiveness shapes political budget cycles - and, by extension, the strength of the political incentives generated by different types of elections.

There are also suggestions in the literature that the 'quality' of elections - as reflected in the absence of electoral inequality and malfeasance - may affect the extent of political budget cycles, though the direction of the effect is ambiguous. On the one hand, political budget cycles may be larger where the quality of elections is low, owing to weaker checks and balances. In this vein, Ehrhart ${ }^{19}$ reports evidence that political budget cycles are larger where the quality of democracy is low. ${ }^{20}$ On the other hand, political budget cycles may be larger where the quality of elections is high, as higher-quality elections are expected to put greater pressure on political leaders to respond to popular demands. Though not focused on fiscal variables, Chauvet and Collier $^{21}$ and Collier and Hoeffler ${ }^{22}$ present evidence along these lines, finding that more 'free and fair' elections result in improved economic management. That said, a significant part of the impact of free and fair elections may be due to competitiveness: free and fair elections are more likely to be competitive, and this higher level of competitiveness may, in turn, be critical to generating stronger incentives for leaders to make concessions to voters.

While there is thus growing interest in the impacts of different 'types' of elections on political budget cycles, the majority of research has focused on public expenditure or the overall size of the fiscal deficit, and has paid less attention to tax collection. This in part reflects greater ambiguity about the expected impact of elections on tax collection. On the one hand, reductions in tax collection may be politically popular. On the other hand, decreases in tax collection may be less visible to taxpayers, may be more costly from the perspective of governments, and may

16 Block, Ferree, and Singh 2003.

${ }_{17}$ Brender and Drazen 2005, 1274.

18 Aidt, Veiga, and Veiga 2011; Efthyvoulou 2012.

19 Ehrhart 2013.

${ }^{20}$ As measured by the Polity IV dataset, Marshall, Jaggers, and Gurr (2012).

${ }^{21}$ Chauvet and Collier 2009.

${ }^{22}$ Collier and Hoeffler 2015. 
necessitate corresponding decreases in public spending if there is a limit to the government's capacity to run fiscal deficits. Following this logic, there is evidence from existing case study research that in some cases governments may have in fact preferred to increase tax collection prior to elections in an effort to accumulate greater resources to use to secure political power. ${ }^{23}$

Consistent with this story, much of the literature finds that political budget cycles in developing countries are driven overwhelmingly by changes in expenditure rather than changes in taxation. ${ }^{24}$ In a more recent study, however, Ehrhart ${ }^{25}$ focuses explicitly on the impact of elections on taxation, drawing on data for a sample of fifty-six developing countries over the period 1980-2006. She finds that elections as a whole have had a negative and significant effect on pre-election tax collection, amounting to about 0.2 per cent of GDP, but that this effect is limited to indirect taxes. She follows the logic of earlier work by Drazen and Eslava ${ }^{26}$ in attributing the latter pattern to the fact that indirect taxes have a much broader incidence than direct taxes, and are thus expected to benefit a much broader group of potential voters.

However, there are reasons to question the theoretical basis for this focus on indirect taxes, which assumes that taxpayers are aware of their tax liabilities, and that political leaders seek to secure political support through direct policy appeals to a broad base of potential voters. Both assumptions may not hold in many developing countries. Political systems are often heavily patronage based, relying on governments' ability to deliver comparatively targeted benefits to politically influential individuals and groups. ${ }^{27}$ Meanwhile, direct taxes are frequently more visible and politically salient than indirect taxes; many taxpayers are only weakly aware of the extent of the indirect tax burden. ${ }^{28}$ For both reasons cuts in direct taxes may be politically rational, and may also offer governments an opportunity to target informal benefits to particular groups more effectively than may sometimes be possible through expanded public spending. Consistent with this view, recent literature has highlighted instances of governments targeting direct tax exemptions at elites in order to secure electoral support. ${ }^{29}$

This ambiguity, in turn, reflects a broader concern that the literature has paid insufficient attention to the mechanisms by which elections may shape pre-election tax collection. Electorally motivated changes in public expenditure are implicitly assumed to reflect relatively explicit policy choices by political leaders, who exercise relatively direct control over public spending. However, these assumptions may not fully hold with respect to changes in tax collection. Most basically, pre-election changes in tax collection appear comparatively likely to be driven not only by changes in policy, but by changes in enforcement or, closely related, the granting of targeted (often relatively informal) tax exemptions. ${ }^{30}$ While governments may

23 Prichard $(2015,126)$ reports such evidence from Kenya, where senior officials explained a desire to increase tax collection prior to a return to democratic elections in 1992 based on a belief that 'elections were not won, they were bought'.

24 Block 2002; Brender and Drazen 2005; Schuknecht 2000.

25 Ehrhart 2013.

26 Drazen and Eslava 2010.

27 Kitschelt and Wilkinson 2007.

28 Bird and Zolt 2005. While the tax literature has tended to argue that indirect taxes are less visible than direct taxes, this is not, of course, universal, and has been challenged elsewhere. Prichard (2015) and Martin and Gabay (2007) note that new or expanded value added taxes (VATs) can sometimes become heavily politicized. For example, the introduction of the VAT prompted large-scale protests in Ghana in 1995 (see also, Osei 2000). That said, in so far as pre-election changes in tax collection reflect changes in enforcement rather than high-profile changes in policy, indirect taxes are likely to remain comparatively invisible to taxpayers.

29 Therkildsen 2012.

30 The latter are a form of tax policy, but are often highly targeted, comparatively informal and potentially temporary, and thus quite distinct from a reduction in, for example, income tax or VAT rates. 
introduce explicit and broad-based reductions in tax rates immediately prior to elections, ${ }^{31}$ it appears at least equally likely that the government may 'instruct' the tax administration to 'go slow' in order to reduce the intensity of the tax burden. This appears to have been the case in Ethiopia, for example, where tax collection declined in the year prior to the reintroduction of competitive elections in 2005, despite the absence of any significant changes in tax policy. Instead, there is a pervasive sense that the Ethiopian government sought to reduce the intensity of tax enforcement in order to secure greater political support. ${ }^{32}$ Meanwhile, the granting of targeted tax incentives and exemptions represents a slightly more formalized variant of the same logic, with exemptions offered in return for explicit political support or donations. ${ }^{33}$ Ethiopia again offers a useful illustration, as the government granted various poorly documented tax incentives, many of them focused on trade taxes, to particular economic sectors in the lead-up to the 2005 elections. ${ }^{34}$ In the same vein, Therkildsen has reported that such exemptions have been an important electoral strategy in Tanzania. ${ }^{35}$

While the distinction between reduced tax rates, weakened enforcement and targeted exemptions is thus critical, a still more fundamental difference between revenue and expenditure is the extent to which these aggregate categories are fully under government control. Increases in public expenditure are, for the most part, controlled by government officials. By contrast, a decline in tax collection may reflect a strategic choice by government leaders, but may equally reflect reduced capacity to collect taxes prior to some elections, owing to resistance by taxpayers or reduced effort by tax administrations. There is significant theory and evidence indicating that tax compliance is likely to be lower where taxpayers have less trust in government. ${ }^{36}$ As such, tax collection may decline prior to elections in which the incumbent government is particularly unpopular, as taxpayers expand efforts to resist, avoid and evade taxation. Prichard has argued that this may not only be a means to reduce tax payments, but may also be a quiet form of political protest and 'tax bargaining', as dissatisfied taxpayers seek to strangle the state's fiscal capacity, and thus increase the likelihood of political change. ${ }^{37}$ Meanwhile, a similar logic may apply to the tax administration, where declining confidence in the incumbent government - or a sense that the government is fragile and not likely to survive the election - may prompt reduced enforcement effort and the expansion of collusion with taxpayers. Both processes may, in turn, be enhanced around elections if the government is hesitant to adopt strong enforcement measures, and if taxpayers seek to exploit this leniency.

The role of reduced capacity in explaining pre-election declines in tax collection finds support in existing case studies. One illustration comes from Ghana, where tax collection declined prior to elections in 1996 and 2000 despite a stated government desire to increase collection. This appears to have reflected expanded public resistance to taxation, which prevented proactive tax reforms, reduced levels of 'quasi-voluntary' compliance and eroded effort within the tax administration. ${ }^{38}$ An even more pronounced example comes from Kenya, where revenue

31 Osei 2000.

32 Prichard 2015.

33 Hassan and Prichard 2013.

34 Prichard 2015.

35 Therkildsen 2012.

36 Levi's (1988) work is best known, as she argues that 'quasi-voluntary' tax compliance is most likely where taxpayers trust the government to deliver reciprocal services, and where they believe that others also pay their fair share. A useful review of studies of the determinants of tax compliance in developing countries is offered by Fjeldstad and Schulz-Herzenberg (2012).

37 Prichard 2015.

38 Prichard 2015. 
declined dramatically in the years prior to the 2002 elections. While a significant part of that decline was attributable to an extended economic crisis, tax officials are adamant that it also reflected declining administrative effort and expanded tax resistance, resulting from declining support for the government. Indeed, some go so far as to describe that expanded resistance as a 'semi-explicit opposition strategy', 39 consistent with the notion that resistance to taxation may in some cases reflect a form of 'tax bargaining' aimed at compelling improvements in governance.

\section{RESEARCH QUESTIONS AND DATA}

Collectively, the preceding discussion focuses attention on two interconnected research questions. First, is there evidence that elections have been associated with pre-election declines in tax collection? Or, alternatively, is there evidence that particular 'types' of elections have been associated with pre-election declines in tax collection? The analysis to follow focuses specifically on the distinct impact of competitive elections, though alternative possibilities from the literature are also explored (and rejected) in the robustness checks. Secondly, if there is evidence that elections have been associated with a decline in pre-election tax collection, what can be said about the mechanisms underpinning this decline? In particular, do declines in tax collection appear to reflect a strategic choice by political leaders responding to electoral pressures, or is there evidence that a lack of capacity to collect revenue among unpopular governments has also played a role?

The starting point for answering these questions is access to newly available and higherquality data on tax collection. The newly created International Centre for Tax and Development Government Revenue Dataset (ICTD GRD) provides dramatically improved data coverage, accuracy and transparency across developing countries. It thus addresses concerns that earlier results may be driven by very incomplete and occasionally inaccurate revenue data for developing countries. The dataset is described in detail in Prichard, Cobham and Goodall, ${ }^{40}$ and has two major advantages. First, it achieves markedly improved data coverage by combining mutually compatible data from multiple international sources, thus filling extensive gaps in the IMF Government Finance Statistics (GFS) by drawing on regional sources and IMF Article IV reports. While the ICTD GRD is not the first such effort, it is more far reaching, transparent and robust than earlier efforts. ${ }^{41}$ Whereas Ehrhart includes only fifty-six developing countries, and a maximum of 1,238 country-year observations over the period 1980-2006, ${ }^{42}$ the ICTD GRD allows the analysis to include 1,870 observations across ninety-eight countries over the period 1980-2010 in the core results. ${ }^{43}$ Meanwhile, the ICTD GRD also improves data accuracy by

${ }^{39}$ Interviews cited in Prichard $(2015,141)$.

40 Prichard, Cobham, and Goodall 2014.

${ }^{41}$ While such merging is potentially problematic from a strict methodological perspective, in practice even IMF researchers themselves have largely abandoned the GFS in favor of combining data from multiple international and country-level sources. See, for example, more limited data efforts described in Benedek et al. (2012) and Keen and Mansour (2009).

42 Ehrhart 2013.

${ }^{43}$ These figures appear to imply significant missing data, with only about twenty observations per country, over thirty years. However, this is misleading, as the vast majority of this missing data comes early in the time series (primarily for post-Soviet states that did not report reliable data until 1994-95) or in the final two years (for countries that are slow to report data), with very limited missing data within individual time series. Excluded are countries with populations less than one million and data for Zimbabwe, which is a major outlier owing to hyperinflation in the 2000s. Excluding the latter does not alter key results, but is analytically appropriate. 
consistently distinguishing between taxes on natural resources and non-resource taxes on domestic businesses and citizens. This is a critical analytical distinction, as we expect elections to primarily affect levels of tax collection from citizens and local businesses, rather than the taxation of resource firms. ${ }^{44}$ However, the distinction is not consistently made in most international data sources, with the risk of 'contaminating' the dependent variable of interest.

Drawing on this data, we are able to construct three dependent variables of interest, each excluding natural resource revenues: total tax revenue collection as a share of GDP (tottax), total direct tax collection as a share of GDP (direct) and total indirect tax collection as a share of GDP (indirect). ${ }^{45}$ While these are the best indicators of tax collection available, it is important to note that they likely do not capture the full range of ways in which governments may reduce taxes prior to elections. In many developing countries, the majority of taxpayers fall below the thresholds for standard income and value-added taxes, but are instead subject to a range of smaller levies that constitute only a tiny share of overall tax collection. ${ }^{46}$ It is possible - and has been suggested elsewhere ${ }^{47}$ - that politicians may reduce enforcement of these smaller taxes in order to secure electoral support. However, such changes would be difficult to detect using aggregate tax-to-GDP ratios. As such, a negative effect of elections on tax collection measured as a share of GDP likely understates the true extent of pre-electoral changes in tax collection, as changes affecting larger tax sources seem likely to be replicated in relation to smaller, but relatively less measurable, taxes.

While the article benefits from improvements in the quality of tax data, it is also able to draw on a growing number of electoral datasets in order to more precisely capture distinct 'types' of elections. The primary source of electoral data is the National Elections Across Democracy and Autocracy (NELDA) dataset, ${ }^{48}$ which provides key descriptive information on all elections worldwide. It is supplemented with data on electoral outcomes from the Database of Political Institutions (DPI), which provides the most complete cross-country information on the shares of electoral support received by the government and opposition in individual elections. ${ }^{49}$

Using these sources, we begin with a variable for all elections (election), which is a binary dummy variable coded 1 for years in which there is an election, and 0 otherwise. Following the literature, the variable includes all executive elections, ${ }^{50}$ as coded by the NELDA dataset. Our primary subsequent interest is then in investigating whether competitive elections have a distinct, and larger, impact on pre-election tax collection. To this end we construct two alternative measures of competitiveness. The more modest version is a dummy variable capturing exclusively contested, multiparty elections that include a legal opposition

${ }^{44}$ Governments often provide reduced taxes to resource firms - particularly in the mining sector - in exchange for informal political contributions. However, there is no clear reason why such concessions should accelerate prior to elections, as any exchange of tax concessions for political contributions can occur at any point in the electoral cycle, and is most likely to be negotiated at the point of establishing specific terms for new mining ventures (see, for example, Ayee 2011, 21).

45 Following standard international classifications, direct taxes include taxes on corporations, income taxes on individuals, property taxes and payroll taxes, but exclude social contributions. Indirect taxes include goods and services taxes (including VAT), excise taxes, trade taxes and 'other' taxes.

46 Joshi, Prichard, and Heady (forthcoming).

47 Fjeldstad and Therkildsen 2008; Prichard 2010; Tendler 2002.

48 Hyde and Marinov 2012.

49 Beck et al. 2001.

${ }^{50}$ Following the literature, executive elections are defined as those in which the position of the effective head of state is contested, where the effective head of state may be an elected president, the leader of the largest party or coalition in parliament, or someone else. 
(election_opp). ${ }^{51}$ The alternative, as discussed above, is to adopt a more restrictive and substantive definition of competitiveness. We thus create a dummy variable for competitive elections (election_comp) that equals 1 if the government wins 60 per cent or less of all the seats in government, as coded by the DPI. ${ }^{52}$ In the robustness checks, we then explore robustness to alternative definitions. ${ }^{53}$

The inclusion of the competitiveness variable raises potential concerns about endogeneity. ${ }^{54}$ Most basically, while the competitiveness of elections is expected to influence pre-election choices about taxation, reductions in pre-election tax collection may also improve incumbents' electoral prospects, and thus increase the margin of electoral victory. However, in practice, potential endogeneity is of limited concern for the core results. Any endogeneity would bias the results against finding a negative relationship between electoral competitiveness and preelection tax collection. ${ }^{55}$ As such, if there is significant endogeneity, then the magnitude of the negative relationship between competitiveness and pre-election tax collection, reported below, should be underestimated, thus strengthening the core argument of the article. A related concern is that declines in tax collection and the level of electoral competitiveness may both be caused by a third factor. One such possibility is that economic crisis or political conflict could contribute to both outcomes. I attempt to account for both by including relevant control variables for economic growth and civil conflict, described below.

An alternative possibility is that the growing unpopularity of an incumbent government may similarly drive both declining tax collection and more competitive elections. This returns us to the discussion of mechanisms presented earlier: to what extent do pre-election declines in taxation reflect declining capacity for collection in the face of taxpayer resistance to unpopular governments, rather than merely strategic choices by government? To answer this question, we propose that if capacity is an important driver of declining pre-election tax collection, then we should expect to see larger declines in tax collection prior to elections in which the incumbent is particularly unpopular. While we would ideally assess government popularity using public opinion polls, these are rarely available - or reliable - in lower-income countries. As such, we instead create a dummy variable that equals 1 if the election results in a transition in power to the opposition (election_transition), as coded by the NELDA dataset. This rests on the belief that an electoral loss by the incumbent is the best available proxy for governments that are particularly unpopular, and which we would thus expect to struggle in securing tax compliance prior to an election. ${ }^{56}$

${ }^{51}$ It is coded by excluding elections for which either of the variables nelda3, nelda4 or nelda 5 is coded 'no' (Hyde and Marinov 2012).

52 There are important debates in the literature about the most appropriate method of measuring electoral competitiveness, and none are perfect (Hyde and Marinov 2012). To an important extent this reflects the fact that a large margin of electoral victory may reflect a lack of competition, or may indicate an incumbent's success in satisfying public demands in the face of a potentially competitive challenge (Gordon and Huber 2007). It is equally possible that a large margin of electoral victory could disguise significant intraparty electoral competition (e.g., Giliomee and Simkin 1999). However, a focus on the margin of victory is both conceptually straightforward and captures the core logic of democratic theory, and for this reason is adopted elsewhere in the literature (Aidt, Veiga, and Veiga 2011; Efthyvoulou 2012), and is supported by recent scholarship on electoral competitiveness in Africa (Rakner and van de Walle 2009).

${ }^{53}$ The use of this variable presumes that actual electoral competitiveness is closely associated with government expectations of competitiveness when making decisions about taxation prior to the election. This seems a relatively safe assumption, in the absence of pre-election polling data.

${ }^{54}$ Gordon and Huber 2007.

55 That is, any endogeneity will generate a spuriously more positive association between competitiveness and elections, as lower pre-election tax collection lowers the level of competitiveness.

56 This is not a perfect measure: incumbents may be highly unpopular without losing elections when elections are not free and fair, while, particularly in well-established democracies, regular democratic transitions often 
Alongside defining the relevant subsets of elections, it is necessary to define the time period over which the effect of elections on pre-election tax collection is expected to occur. Electorally motivated reductions in tax collection seem likely to begin somewhere from six to twelve months (or more) prior to the election. ${ }^{57}$ As such, when an election occurs early in the calendar year, the tax effects of the election are more likely to be felt in the calendar year prior to the election. By the same token, a focus on tax effects in the same calendar year will primarily capture post-election impacts. As such, for elections that occur early in the calendar year, the 'effective' election year for detecting effects on taxation is the year prior, as follows:

$$
\begin{aligned}
\text { Election_e }_{i, t} & =\text { Actual_Election }_{i, t+1} \quad \text { if election_month } h_{i, t+1} \leq k \\
& =\text { Actual_Election }_{i, t} \quad \text { otherwise, }
\end{aligned}
$$

where election_ek is the effective election year for detecting impacts on taxation, actual_election is the calendar year of the election and $k$ takes a value of 1 through 12 and captures the 'cut-off' point for recoding the effective election year, with elections earlier than month $k$ expected to have fiscal effects in the year prior to the election. Decisions about the appropriate value of $k$ reflect assumptions about the relevant 'lag' between the tax effects of an election and the election itself. Existing studies generally adopt a value of $k$ ranging from three to six months into the year. The core results here take a middle ground by setting $k=5$, denoted as election_e5, thus looking for fiscal effects in the year prior when elections occur in the first five months of the calendar year. The impact of alternative coding decisions is then explored at length in order to ensure the robustness of the results.

Finally, the results include a standard set of control variables. The log level of per capita income $(l g d p)$ captures the expectation that the tax share of GDP will be higher where incomes are higher. The share of agriculture in the national economy (agric) reflects the greater difficulty of taxing agricultural production. The level of imports (imports) is expected to have a positive impact on tax collection, by virtue of taxes explicitly on trade as well as the greater ease of taxing more formal economic transactions. The level of inflation (inflation) is expected to have a negative impact on the value of tax collection, while tax collection is expected to be higher when the per capita growth rate is higher (growthpc). All data are taken from the World Development Indicators (WDI) database. In addition, the regressions include two control variables that have often been overlooked in recent studies: the existence of a civil war (civil_war) - constructed using data from the Uppsala Conflict Data Program/International Peace Research Institute (UCDP/PRIO) dataset, ${ }^{58}$ which is expected to reduce tax collection and the level of non-tax revenue as a share of GDP (totnontax), drawn from the ICTD GRD, ${ }^{59}$ which has been shown to lead to reduced tax effort. ${ }^{60}$ Finally, following recent studies, the robustness checks also introduce controls for the level of urbanization (urban), the share of the

(F'note continued)

occur that do not indicate outright hostility toward the outgoing government. However, an incumbent loss appears to be the best indicator of popular hostility to an incumbent government and, as described below, the results suggest that this is an empirically useful distinction.

57 While not discussed in the literature, the length of the 'lag' seems intuitively likely to be longer for tax reductions than changes in public expenditure, as tax benefits are often more difficult to target, and are constrained by the timing of tax payments throughout the fiscal year, thus making it more difficult to concentrate benefits immediately prior to an election.

58 Themnér and Wallensteen 2014.

59 Prichard, Cobham, and Goodall 2014.

60 Bornhorst, Gupta, and Thornton 2008. 
population under the age of fourteen (under14) and the share of the population over the age of sixty-five (over65), also from the WDI.

\section{EMPIRICAL STRATEGY}

Following the literature, we employ a dynamic estimation model of the form:

$$
\text { Tax }_{i, t}=\varphi \text { Tax }_{i, t-1}+\beta_{1} \text { Election_es }_{i, t}+X_{i, t-1}^{\prime} \delta+\alpha_{i}+\lambda_{t}+e_{i, t},
$$

where the dependent variable, Tax, represents total tax revenue (tottax), direct tax revenue (direct) or indirect tax revenue (indirect) as shares of GDP; Election_e5 is our key independent variable; $X$ represents the battery of control variables; $\alpha$ are the country fixed effects; $\lambda$ are year fixed effects and $e$ is the error term. The lagged dependent variable is included in order to account for the persistence of tax collection over time and any potential mean-reverting dynamics. The analysis includes fixed effects in order to focus on within-country variation in tax collection in response to elections.

However, the fixed-effects estimator is biased when employed alongside a lagged dependent variable, as the lagged dependent variable is correlated with the error term. ${ }^{61}$ The extent of this bias declines in the length of the time series, and is likely to be relatively modest but nonnegligible given that the data cover three decades. ${ }^{62}$ The widely used Arellano-Bond Generalized Method of Moments (GMM) estimator is the most commonly used alternative, and has dominated the recent literature. ${ }^{63}$ However, it has been criticized both for being a theoretical 'black box' and for its sensitivity to choices about model specification, leading Brender and Drazen, among others, to prefer the fixed-effects estimator, despite the modest bias that it entails. ${ }^{64}$ As such, all results are reported employing both the fixed-effects estimator and the System-GMM version of the Arellano-Bond estimator, the latter of which employs both lagged first differences and lagged levels of the explanatory variables as instruments. The Sys-GMM results are computed using Windmeijer robust standard errors, while the relevant tables report tests for second-order autocorrelation as well as the Hansen test for invalid instruments. ${ }^{65}$

In order to explore the conditional impacts of different types of elections, the basic model is subsequently extended. To begin, we wish to explore the impact of focusing only on contested, multiparty elections (election_e5_opp) rather than all executive elections (election_e5). In order to do so, the model is extended to include two election variables: the baseline elections variable (election_e5) and the variable representing the more limited subset of elections of interest (election_e5_opp), as follows:

$$
\operatorname{Tax}_{i, t}=\varphi \text { Tax }_{i, t-1}+\beta_{1} \text { Election_e5 }_{i, t}+\beta_{2} \text { Election_e5_opp } p_{i, t}+X_{i, t-1}^{\prime} \delta+\alpha_{i}+\lambda_{t}+e_{i, t},
$$

Because contested elections are a subset of all elections, the interpretation of the results is similar to an interaction model. The coefficient, $\beta_{1}$, on the baseline elections term (election_e5) tells us the independent effect of elections that are not contested. The coefficient, $\beta_{2}$, on the subset of elections of interest (election_e5_opp) tells us whether that subset of elections (contested elections) is statistically significantly different from the baseline group of elections (uncontested elections). Finally, the overall effect of the subset of elections of interest - in this

${ }^{61}$ Nickell 1981.

62 Brender and Drazen 2005.

${ }^{63}$ Blundell and Bond 1998.

${ }^{64}$ Brender and Drazen 2005.

65 Roodman 2006; Roodman 2009. 
case, contested elections - can be calculated as the linear combination of coefficients $\beta_{1}$ and $\beta_{2}$, which is reported in all of the tables to follow. The value of this linear combination is essentially identical to the result if we run a simpler regression that includes only the subset of elections of interest, as follows:

$$
\operatorname{Tax}_{i, t}=\varphi \text { Tax }_{i, t-1}+\beta_{1} \text { Election_e5_opp } p_{i, t}+X_{i, t-1}^{\prime} \delta+\alpha_{i}+\lambda_{t}+e_{i, t} .
$$

The added value of also including the baseline elections term, as in Equation 3, is that it allows us to formally test whether the subset of elections of interest is statistically significantly different from all other elections. Having thus tested the distinct impact of contested elections, we proceed to test whether more substantively competitive elections (election_e5_comp) have a distinct impact on tax collection compared to contested elections (elections_e5_opp) more generally. We use contested elections as the baseline for comparison, rather than all elections (election_e5), as the former is a more interesting and meaningful comparison. ${ }^{66}$ This gives us the following specification:

$$
\operatorname{Tax}_{i, t}=\operatorname{stax}_{i, t-1}+\beta_{1} \text { Election_e5_opp } p_{i, t}+\beta_{2} \text { Election_e5_comp }+X_{i, t-1}^{\prime} \delta+\alpha_{i}+\lambda_{t}+e_{i, t}
$$

In turn, the variable for competitive elections, election_e5_comp, can be replaced by other subsets of elections in order to test a variety of other possibilities suggested by the existing literature.

\section{RESULTS}

We begin with simple descriptive statistics. Figure 1 presents data on the annual change in tax collection in all election years, and then in years in which there are particular types of elections. While tax collection has generally been lower in election years than non-election years, the difference between the two is comparatively modest. Tax collection has increased, on average, even in election years, though more slowly than in non-election years. More strikingly, the descriptive data are consistent with the predictions detailed so far. While elections in general appear to have had at most a modest impact on tax collection, tax collection has tended to fall much more significantly during years in which there have been competitive elections. This has been particularly true of competitive elections in which the incumbent has been replaced, which is consistent with the view that declining tax collection may have been driven by both political strategy and reduced capacity among unpopular governments. The table also includes first elections and free and fair elections, ${ }^{67}$ both of which have been raised in the literature, and neither shows a strong pattern. ${ }^{68}$

Moving beyond simple descriptive statistics, Table 1 presents the core regression results, employing the fixed-effects and Sys-GMM estimators in turn. Moving from left to right, the first three columns report results focusing on all elections (election_e5), contested elections (election_e5_opp) and competitive elections (election_e5_comp) employing the fixed-effects estimator, while the columns to the right report the same relationships using the Sys-GMM estimator.

66 That said, the results are essentially unchanged if we employ all elections as the baseline.

67 Specifically, it excludes elections that involved boycotts by the opposition (variable: nelda 14), harassment of the opposition (nelda15), the cancellation of results favoring either the incumbent or the opposition (nelda 34 and nelda 32), reports of fraud by election monitors (nelda47) or refusals to participate by electoral monitors owing to perceived electoral fraud (nelda49).

68 We also subject both variables to more formal econometric tests, and again find that neither exhibits any consistent and significant impact on pre-election tax collection. Results for free and fair elections are reported in Appendix Table A1. 


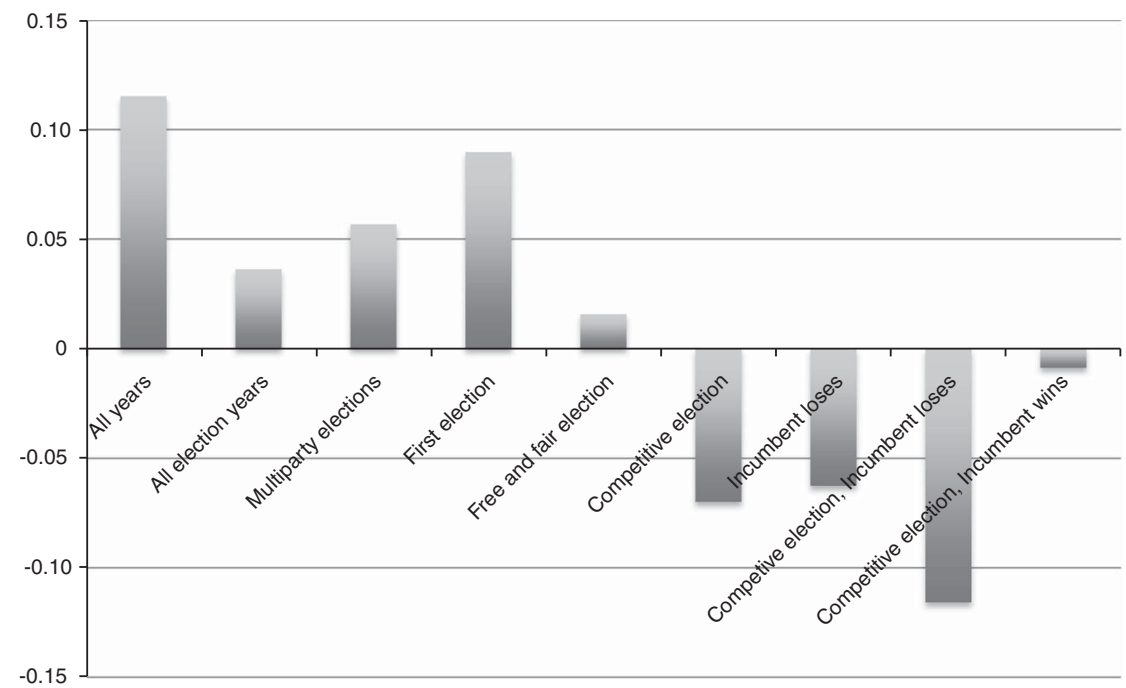

Fig. 1. Election year changes in tax collection.

Source: authors' calculations.

The basic pattern of results is clear-cut. There is no evidence that elections in general (election_e5) have a negative impact on pre-election tax collection, nor is there any evidence of such an effect when focusing exclusively on contested elections (election_e5_opp). By sharp contrast, there is strong and statistically significant support for the existence of a negative relationship between competitive elections and tax collection. In both the fixed-effects and Sys-GMM results, there is a statistically significant negative coefficient on election_e5_comp, signalling that competitive elections have a significantly more negative impact on tax collection than all other contested elections. Meanwhile, the overall impact of competitive elections (row $\beta_{1}+\beta_{2}$ ) is in both cases negative and significant. The magnitude of the effect is substantial, with competitive elections estimated to lead to a 0.27 per cent of GDP decline in tax collection in the fixed-effects estimates, and a 0.39 per cent of GDP decline in the Sys-GMM estimates.

An immediate potential concern is that measuring electoral competitiveness is inherently challenging. The choice of a cut-off point in deciding what constitutes competitiveness is somewhat arbitrary. Whereas the core results classify an election as competitive if the winning coalition controls less than 60 per cent of seats, Table 2 reports results when the threshold for competitiveness is set to either 50 per cent (election_e5_comp50) or 70 per cent (election_e5_comp70) of seats. Similarly, relying on the number of seats in government to measure competitiveness may be less accurate than relying on the overall share of the vote received by the winning party or coalition. Therefore Table 2 also reports results when employing vote share, testing the use of 50 per cent (election_e5_comp_vote50), 60 per cent (election_e5_comp_vote) and 70 per cent (election_e5_comp_vote70) of the vote as the threshold for competitiveness.

The results are not only consistent with the argument, but add additional support. The results are essentially unchanged when we employ the share of the vote instead of the share of seats to define competitiveness. When the cut-off point for competitiveness is lowered to 50 per cent of seats, thus requiring a higher degree of competitiveness, we find the expected increase in the magnitude of the effect (reported in Columns 3 and 4) to between 0.4 and 0.5 per cent of GDP. When the cut-off point for competitiveness is increased to 70 per cent of seats - thus including a 
TABLE 1 Effect of Different Election Types on Tax Revenue

\begin{tabular}{|c|c|c|c|c|c|c|}
\hline & (1) & (2) & (3) & (4) & (5) & (6) \\
\hline & $\begin{array}{c}\text { All } \\
\text { Elections }\end{array}$ & $\begin{array}{l}\text { Multiparty } \\
\text { Elections }\end{array}$ & $\begin{array}{l}\text { Competitive } \\
\text { Elections }\end{array}$ & All Elections & $\begin{array}{l}\text { Multiparty } \\
\text { Elections }\end{array}$ & $\begin{array}{l}\text { Competitive } \\
\text { Elections }\end{array}$ \\
\hline & $\begin{array}{l}\text { Fixed- } \\
\text { Effects }\end{array}$ & Fixed-Effects & Fixed-Effects & $\begin{array}{l}\text { System- } \\
\text { GMM }\end{array}$ & System-GMM & System-GMM \\
\hline $\begin{array}{l}\text { L.TotTax } \\
\text { election_e5 }\end{array}$ & $\begin{array}{c}0.7534 * * * \\
(0.0185) \\
-0.0009 \\
(0.0009)\end{array}$ & $\begin{array}{c}0.7535^{* * *} \\
(0.0184) \\
-0.0012 \\
(0.0021)\end{array}$ & $\begin{array}{c}0.7533 * * * \\
(0.0184)\end{array}$ & $\begin{array}{c}0.7556 * * * \\
(0.0556) \\
-0.0008 \\
(0.0011)\end{array}$ & $\begin{array}{c}0.7513 * * * \\
(0.0605) \\
-0.0000 \\
(0.0020)\end{array}$ & $\begin{array}{l}0.7536 * * * \\
(0.0562)\end{array}$ \\
\hline $\begin{array}{l}\text { election_e5_opp } \\
\text { election_e5_comp }\end{array}$ & & $\begin{array}{c}0.0003 \\
(0.0022)\end{array}$ & $\begin{array}{r}0.0006 \\
(0.0013) \\
-0.0033^{* *} \\
(0.0016)\end{array}$ & & $\begin{array}{c}-0.0011 \\
(0.0023)\end{array}$ & $\begin{array}{r}0.0010 \\
(0.0014) \\
-0.0049 * * \\
(0.0020)\end{array}$ \\
\hline $\operatorname{lgdp}$ & $\begin{array}{c}-0.0000 \\
(0.0022)\end{array}$ & $\begin{array}{c}-0.0000 \\
(0.0022)\end{array}$ & $\begin{array}{l}0.0000 \\
(0.0022)\end{array}$ & $\begin{array}{l}0.0025 \\
(0.0018)\end{array}$ & $\begin{array}{l}0.0024 \\
(0.0019)\end{array}$ & $\begin{array}{l}0.0023 \\
(0.0015)\end{array}$ \\
\hline Agric & $\begin{array}{r}-0.0002^{* *} * \\
(0.0001)\end{array}$ & $\begin{array}{r}-0.0002 * * \\
(0.0001)\end{array}$ & $\begin{array}{r}-0.0002 * * \\
(0.0001)\end{array}$ & $\begin{array}{r}-0.0002 * \\
(0.0001)\end{array}$ & $\begin{array}{r}-0.0002 * * \\
(0.0001)\end{array}$ & $\begin{array}{r}-0.0002 * * \\
(0.0001)\end{array}$ \\
\hline Imports & $\begin{array}{c}0.0002 * * * \\
(0.0000)\end{array}$ & $\begin{array}{c}0.0002 * * * \\
(0.0000)\end{array}$ & $\begin{array}{c}0.0002 * * * \\
(0.0000)\end{array}$ & $\begin{array}{r}0.0003 * * \\
(0.0001)\end{array}$ & $\begin{array}{r}0.0003 * * \\
(0.0001)\end{array}$ & $\begin{array}{c}0.0003^{* * * *} \\
(0.0001)\end{array}$ \\
\hline Civil_War & $\begin{array}{r}-0.0002 \\
(0.0014)\end{array}$ & $\begin{array}{r}-0.0002 \\
(0.0014)\end{array}$ & $\begin{array}{r}-0.0001 \\
(0.0014)\end{array}$ & $\begin{array}{r}-0.0010 \\
(0.0016)\end{array}$ & $\begin{array}{r}-0.0016 \\
(0.0019)\end{array}$ & $\begin{array}{c}-0.0016 \\
(0.0018)\end{array}$ \\
\hline TotNonTax & $\begin{array}{r}-0.0266^{* *} * \\
(0.0112)\end{array}$ & $\begin{array}{r}-0.0266^{* *} \\
(0.0112)\end{array}$ & $\begin{array}{r}-0.0266^{* *} \\
(0.0113)\end{array}$ & $\begin{array}{c}-0.0649 * * * \\
(0.0164)\end{array}$ & $\begin{array}{c}-0.0682 * * * \\
(0.0163)\end{array}$ & $\begin{array}{c}-0.0675^{* * *} \\
(0.0148)\end{array}$ \\
\hline Inflation & $\begin{array}{r}0.0000 * * \\
(0.0000)\end{array}$ & $\begin{array}{r}0.0000 * * \\
(0.0000)\end{array}$ & $\begin{array}{r}0.0000 * * \\
(0.0000)\end{array}$ & $\begin{array}{r}0.0000 * * \\
(0.0000)\end{array}$ & $\begin{array}{l}0.0000 \\
(0.0000)\end{array}$ & $\begin{array}{c}0.0000 * * * \\
(0.0000)\end{array}$ \\
\hline Growthpc & $\begin{array}{l}0.0002 * \\
(0.0001)\end{array}$ & $\begin{array}{l}0.0002 * \\
(0.0001)\end{array}$ & $\begin{array}{l}0.0002^{*} \\
(0.0001)\end{array}$ & $\begin{array}{l}0.0002^{*} \\
(0.0001)\end{array}$ & $\begin{array}{l}0.0002^{*} \\
(0.0001)\end{array}$ & $\begin{array}{c}0.0002 * \\
(0.0001)\end{array}$ \\
\hline$\beta 1+\beta 2$ & & $\begin{array}{l}-0.0009 \\
(0.0010)\end{array}$ & $\begin{array}{r}-0.0027 * * \\
(0.0012)\end{array}$ & & $\begin{array}{r}-0.0012 \\
(0.0012)\end{array}$ & $\begin{array}{r}-0.0039 * * \\
(0.0015)\end{array}$ \\
\hline $\operatorname{AR}(1)$ & & & & 0.000 & 0.000 & 0.000 \\
\hline $\mathrm{AR}(2)$ & & & & 0.338 & 0.332 & 0.339 \\
\hline Hansen & & & & 0.390 & 0.979 & 0.998 \\
\hline No. of obs. & 1,870 & 1,870 & 1,870 & 1,870 & 1,870 & 1,870 \\
\hline No. of countries & 98 & 98 & 98 & 98 & 98 & 98 \\
\hline $\mathrm{R}^{2}$ & 0.689 & 0.689 & 0.689 & & & \\
\hline
\end{tabular}

Notes: standard errors in parentheses. Fixed-effects results are calculated with robust standard errors. Sys-GMM results are based on the two-step Sys-GMM procedure with Windmeijer standard errors. The results reported here are based on a simple specification, with the LDV and elections variable treated as endogenous, with the instrument matrix collapsed, while the control variables are treated as exogenous. Alternative specifications are reported in the robustness tests. The p-values reported for the Hansen statistic are for the null hypothesis that instruments are valid. The values reported for AR (2) are p-values for tests of second-order autocorrelation. The coefficients in row ' $\beta 1+\beta 2$ ' capture the total magnitude and significance of the impact of the subset of elections reflected in $\beta 2$. $* p<0.10$, $* * \mathrm{p}<0.05, * * * \mathrm{p}<0.01$.

set of elections in which the opposition poses at best a marginal threat - we find, as expected, that most of the relevant coefficients lose significance and decline in magnitude. In the remaining analysis we continue to focus on the 60 per cent threshold, for consistency, but occasionally also test the results when employing the more restrictive threshold of 50 per cent of seats.

With these baseline findings as a starting point, Table 3 follows Ehrhart ${ }^{69}$ in presenting results in which the dependent tax variable is divided into its direct and indirect tax components. Results are reported using both the fixed-effects and Sys-GMM estimators, examining the impacts, in turn, of all elections (election_e5) and competitive elections (election_e5_comp).

${ }^{69}$ Ehrhart 2013. 
тав Lе 2 Re-estimating Results Using Alternative Definitions of Competitiveness

\begin{tabular}{|c|c|c|c|c|c|c|c|c|c|c|c|c|}
\hline & (1) & (2) & (3) & (4) & (5) & (6) & (7) & (8) & (9) & (10) & (11) & (12) \\
\hline & Comp & Comp & Comp50 & Comp50 & Comp70 & Comp70 & Comp_Vote & Comp_Vote & Comp_Vote50 & Comp_Vote50 & Comp_Vote70 & Comp_Vote70 \\
\hline & $\mathrm{FE}$ & Sys-GMM & $\mathrm{FE}$ & Sys-GMM & $\mathrm{FE}$ & Sys-GMM & $\mathrm{Fe}$ & Sys-GMM & $\mathrm{Fe}$ & Sys-GMM & $\mathrm{Fe}$ & Sys-GMM \\
\hline L.TotTax & $\begin{array}{c}0.7533 * * * * \\
(0.0184)\end{array}$ & $\begin{array}{c}0.7536 * * * \\
(0.0562)\end{array}$ & $\begin{array}{c}0.7526^{* * * *} \\
(0.0184)\end{array}$ & $\begin{array}{c}0.7895 * * * \\
(0.0610)\end{array}$ & $\begin{array}{c}0.7533 * * * \\
(0.0184)\end{array}$ & $\begin{array}{c}0.7641 * * * * \\
(0.0512)\end{array}$ & $\begin{array}{c}0.7530 * * * \\
(0.0183)\end{array}$ & $\begin{array}{c}0.8419 * * * \\
(0.0464)\end{array}$ & $\begin{array}{c}0.7528 * * * \\
(0.0183)\end{array}$ & $\begin{array}{c}0.8384 * * * \\
(0.0518)\end{array}$ & $\begin{array}{c}0.7534 * * * \\
(0.0182)\end{array}$ & $\begin{array}{c}0.8110^{* * * *} \\
(0.0676)\end{array}$ \\
\hline election_e5_opp & $\begin{array}{l}0.0006 \\
(0.0013)\end{array}$ & $\begin{array}{l}0.0010 \\
(0.0014)\end{array}$ & $\begin{array}{l}0.0002 \\
(0.0011)\end{array}$ & $\begin{array}{c}-0.0003 \\
(0.0013)\end{array}$ & $\begin{array}{l}0.0006 \\
(0.0018)\end{array}$ & $\begin{array}{r}-0.0001 \\
(0.0021)\end{array}$ & $\begin{array}{l}0.0001 \\
(0.0012)\end{array}$ & $\begin{array}{r}-0.0005 \\
(0.0015)\end{array}$ & $\begin{array}{c}-0.0002 \\
(0.0011)\end{array}$ & $\begin{array}{c}-0.0004 \\
(0.0014)\end{array}$ & $\begin{array}{l}0.0009 \\
(0.0014)\end{array}$ & $\begin{array}{c}0.0007 \\
(0.0017)\end{array}$ \\
\hline election_e5_comp & $\begin{array}{r}-0.0033^{* *} \\
(0.0016)\end{array}$ & $\begin{array}{r}-0.0049^{* *} \\
(0.0020)\end{array}$ & & & & & & & & & & \\
\hline election_e5_comp50 & & & $\begin{array}{c}-0.0042^{* * *} \\
(0.0016)\end{array}$ & $\begin{array}{r}-0.0046^{* *} \\
(0.0018)\end{array}$ & & & & & & & & \\
\hline election_e5_comp70 & & & & & $\begin{array}{c}-0.0024 \\
(0.0020)\end{array}$ & $\begin{array}{c}-0.0024 \\
(0.0024)\end{array}$ & & & & & & \\
\hline election_e5_comp_vote & & & & & & & $\begin{array}{c}-0.0029^{*} \\
(0.0017)\end{array}$ & $\begin{array}{c}-0.0039^{*} \\
(0.0021)\end{array}$ & & & & \\
\hline election_e5_comp_vote50 & & & & & & & & & $\begin{array}{l}-0.0028 \\
\quad(0.0017)\end{array}$ & $\begin{array}{c}-0.0031^{*} \\
(0.0019)\end{array}$ & & \\
\hline election_e5_comp_vote70 & & & & & & & & & & & $\begin{array}{r}-0.0039 * * \\
(0.0017)\end{array}$ & $\begin{array}{r}-0.0045^{* *} * \\
(0.0020)\end{array}$ \\
\hline$\beta 1+\beta 2$ & $\begin{array}{r}-0.0027 * * \\
(0.0012)\end{array}$ & $\begin{array}{r}-0.0038^{* *} \\
(0.0015)\end{array}$ & $\begin{array}{c}-0.0041^{* * *} * \\
(0.0014)\end{array}$ & $\begin{array}{c}-0.0049 * * * \\
(0.0014)\end{array}$ & $\begin{array}{c}-0.0018 \\
(0.0011)\end{array}$ & $\begin{array}{l}-0.0025 * \\
(0.0013)\end{array}$ & $\begin{array}{r}-0.0028 * * \\
(0.0013)\end{array}$ & $\begin{array}{r}-0.0044 * * \\
(0.0018)\end{array}$ & $\begin{array}{r}-0.0030 * * \\
(0.0014)\end{array}$ & $\begin{array}{r}-0.0035^{* *} \\
(0.0017)\end{array}$ & $\begin{array}{r}-0.0030^{* *} \\
(0.0012)\end{array}$ & $\begin{array}{r}-0.0038^{* *} \\
(0.0017)\end{array}$ \\
\hline $\mathrm{AR}(1)$ & & 0.000 & & 0.000 & & 0.000 & & 0.000 & & 0.000 & & 0.000 \\
\hline $\mathrm{AR}(2)$ & & 0.339 & & 0.312 & & 0.344 & & 0.359 & & 0.354 & & 0.372 \\
\hline Hansen & & 0.998 & & 0.999 & & 0.970 & & 0.994 & & 0.996 & & 0.983 \\
\hline No. of obs & 1,870 & 1,870 & 1,870 & 1,870 & 1,870 & 1,870 & 1,870 & 1,870 & 1,870 & 1,870 & 1,870 & 1,870 \\
\hline No. of countries & & 98 & & 98 & & 98 & & 98 & 98.000 & 98.000 & 98.000 & 98.000 \\
\hline $\mathrm{R}^{2}$ & 0.689 & & 0.689 & & 0.689 & & 0.689 & & 0.689 & & 0.689 & \\
\hline
\end{tabular}

Notes: standard errors in parentheses. The elections variable in Columns 1-4 is for all executive elections. The results in Columns 1, 3 and 5 employ fixed effects, while the results in Columns 2, 4 and 6 are based on the two-step Sys-GMM procedure with Windmeijer standard errors. The p-values reported for the Hansen statistic are for the null hypothesis that instruments are valid. The values reported for AR(2) are p-values for tests of second-order autocorrelation. The coefficients in row ' $\beta 1+\beta 2$ ' capture the total magnitude and significance of the impact of the subset of elections reflected in $\beta 2$. Estimates all include the standard set of controls - lgdp, agric, imports, civil_war, totnontax, inflation and growthpc - though they are not reported here to conserve space. Comp60 denotes that the government controls less than 60 per cent of seats in government, Comp 50 denotes less than 50 per cent, Comp 70 denotes less than 70 per cent. Comp_vote denotes the government winning less than 60 per cent of the total votes in legislative elections. $* \mathrm{p}<0.10, * * \mathrm{p}<0.05, * * * \mathrm{p}<0.01$ 


\begin{tabular}{|c|c|c|c|c|c|c|c|c|}
\hline & (1) & (2) & (3) & (4) & (5) & (6) & (7) & (8) \\
\hline & $\begin{array}{l}\text { Direct: All } \\
\text { Elections }\end{array}$ & $\begin{array}{l}\text { Direct: All } \\
\text { Elections }\end{array}$ & $\begin{array}{l}\text { Indirect: All } \\
\text { Elections }\end{array}$ & $\begin{array}{l}\text { Indirect: All } \\
\text { Elections }\end{array}$ & $\begin{array}{c}\text { Direct: } \\
\text { Competitive } \\
\text { Elections }\end{array}$ & $\begin{array}{c}\text { Direct: } \\
\text { Competitive } \\
\text { Elections }\end{array}$ & $\begin{array}{l}\text { Indirect: } \\
\text { Competitive } \\
\text { Elections }\end{array}$ & $\begin{array}{c}\text { Indirect: } \\
\text { Competitive } \\
\text { Elections }\end{array}$ \\
\hline & $\mathrm{FE}$ & Sys-GMM & $\mathrm{FE}$ & Sys-GMM & FE & Sys-GMM & $\mathrm{FE}$ & Sys-GMM \\
\hline L.Direct & $\begin{array}{c}0.7925 * * * \\
(0.0337)\end{array}$ & $\begin{array}{c}0.8229 * * * \\
(0.0642)\end{array}$ & & & $\begin{array}{c}0.7919 * * * \\
(0.0340)\end{array}$ & $\begin{array}{c}0.8652 * * * \\
(0.0506)\end{array}$ & & \\
\hline L.Indirect & & & $\begin{array}{c}0.6843 * * * \\
(0.0293)\end{array}$ & $\begin{array}{c}0.6945 * * * \\
(0.0681)\end{array}$ & & & $\begin{array}{c}0.6843 * * * \\
(0.0292)\end{array}$ & $\begin{array}{c}0.7309 * * * \\
(0.0621)\end{array}$ \\
\hline election_e5 & $\begin{array}{l}-0.0003 \\
(0.0005)\end{array}$ & $\begin{array}{r}-0.0007 \\
(0.0005)\end{array}$ & $\begin{array}{r}-0.0008 \\
(0.0007)\end{array}$ & $\begin{array}{r}-0.0006 \\
(0.0009)\end{array}$ & & & & \\
\hline election_e5_comp & & & & & $\begin{array}{r}-0.0013^{*} \\
(0.0007)\end{array}$ & $\begin{array}{c}-0.0012 * \\
(0.0006)\end{array}$ & $\begin{array}{c}-0.0013^{*} \\
(0.0007)\end{array}$ & $\begin{array}{r}-0.0019 * * \\
(0.0008)\end{array}$ \\
\hline $\operatorname{AR}(1)$ & & 0.000 & & 0.002 & & 0.000 & & 0.002 \\
\hline $\operatorname{AR}(2)$ & & 0.712 & & 0.276 & & 0.572 & & 0.272 \\
\hline Hansen & & 0.448 & & 0.271 & & 0.728 & & 0.810 \\
\hline No. of obs. & 1,551 & 1,551 & 1,542 & 1,542 & 1,551 & 1,551 & 1,542 & 1,542 \\
\hline $\begin{array}{l}\text { No. of countries } \\
\mathrm{R}^{2}\end{array}$ & $\begin{array}{l}96 \\
0.692\end{array}$ & 96 & $\begin{array}{l}95 \\
0.538\end{array}$ & 95 & $\begin{array}{l}96 \\
0.692\end{array}$ & 96 & $\begin{array}{l}95 \\
0.538\end{array}$ & 95 \\
\hline
\end{tabular}

Notes. standard errors in parentheses. The elections variable in Columns 1-4 is for all executive elections. The results in Columns 1, 3, 5 and 7 employ fixed effects, while the results in Columns 2, 4, 6 and 8 are based on the two-step Sys-GMM procedure with Windmeijer standard errors. The p-values
reported for the Hansen statistic are for the null hypothesis that instruments are valid. The values reported for AR(2) are p-values for tests of second-order autocorrelation. Estimates all include the standard set of controls - lgdp, agric, imports, civil_war, totnontax, inflation and growthpc - though they are not reported here to conserve space. $* \mathrm{p}<0.10, * * \mathrm{p}<0.05, * * * \mathrm{p}<0.01$. 
Again, the initial results tell a clear story: elections in general have no significant effect on either direct or indirect taxes, while competitive elections have a negative impact on both. This reaffirms the distinct impact of competitive elections, while there is no evidence that elections disproportionately affect either direct or indirect taxes. As discussed earlier, this is not necessarily surprising when the focus is on developing countries, as the role of patronage politics, coupled with the low 'visibility' of indirect taxes, may make reduced collection of direct taxes a useful electoral strategy despite their relatively narrow incidence.

While there is thus evidence that political budget cycles that affect taxation are limited to competitive elections, there remains a question of mechanisms: Does declining tax collection prior to elections reflect a strategic choice by governments aimed at securing electoral support through tax concessions, or might it also be driven by reduced technical and political capacity to collect taxes in the face of taxpayer resistance and diminished administrative effort? While the data do not offer any direct way to make this distinction, if reduced capacity is an important factor then we would expect a larger decline in tax collection prior to elections in which the incumbent is more unpopular, which we capture by focusing on cases in which the incumbent is defeated. While using electoral defeat as a proxy for popularity is obviously imperfect, it has particular appeal in developing countries, where the wide range of electoral advantages generally enjoyed by incumbents has meant that electoral transitions have frequently been a signal of deep popular disenchantment with incumbents.

With this in mind, Table 4 presents results that attempt to identify these mechanisms, using fixed-effects (Columns 1-5) and Sys-GMM (Columns 6-10) in turn. The first column of each set of results again reports the impact of competitive elections, as a point of reference. Column 2 presents results looking at the distinct impact of transitional elections, in which the incumbent is replaced by a new party (election_e5_transition). The results indicate that transitional elections have a significant and negative impact on tax collection. However, interpreting this result is challenging, for two reasons. Most basically, the significance of the result is weaker than that for competitive elections and, as reflected in the robustness checks, is somewhat more sensitive to alternative choices about sample and model specification. Of greater analytical interest, there is significant overlap between competitive elections and transitional elections.

There is corresponding value in attempting to distinguish between the two. To this end, Columns 3 through 5 look separately at elections (1) that are both transitional and competitive, (election_e5_comp_trans), (2) that are competitive, but in which the incumbent is re-elected (election_e5_comp_notrans) and (3) in which the incumbent is replaced, but the election is not competitive (election_e5_trans_uncomp). The results appear to hold two key messages, which echo the descriptive data presented earlier. First, electoral competitiveness is critical. The negative impact of elections on tax collection is entirely limited to competitive elections, whereas the impact of elections in which the incumbent has been replaced, but which were not competitive, is insignificant. ${ }^{70}$ Secondly, the overall decline in tax collection is largest for

\footnotetext{
${ }^{70}$ The negative sign on transitional elections that are uncompetitive is somewhat surprising, as we might expect governments facing likely defeat to be particularly aggressive in seeking to purchase support though tax cuts. There appear to be two possible explanations. First, governments facing overwhelming unpopularity may simply not cut taxes aggressively, either owing to a lack of utility or a preference for maximizing revenue while still in office. Secondly, this result may be a quirk of the data: elections in which the incumbent party is replaced, as coded in existing datasets, capture both elections in which the incumbent party is defeated and those in which the incumbent leader steps down or the ruling party is dissolved. The latter could include cases, for example, where a sitting president opts not to run for office and their party loses favor as a result, or where the party system itself is very fluid. In both cases our variable is capturing a transition, but not necessarily the defeat of the incumbent, and a perusal of cases within the dataset suggests that this is relevant in some cases.
} 
TABLE 4 Distinguishing between Competitive and Transitional Elections

\begin{tabular}{|c|c|c|c|c|c|c|c|c|c|c|}
\hline & (1) & (2) & (3) & (4) & (5) & (6) & (7) & (8) & (9) & (10) \\
\hline & $\begin{array}{c}\text { All } \\
\text { Competitive }\end{array}$ & $\begin{array}{c}\text { All } \\
\text { Transition }\end{array}$ & $\begin{array}{l}\text { Competitive, } \\
\text { Transition }\end{array}$ & $\begin{array}{l}\text { Competitive, No } \\
\text { Transition }\end{array}$ & $\begin{array}{l}\text { Transition, } \\
\text { Uncompetitive }\end{array}$ & $\begin{array}{c}\text { All } \\
\text { Competitive }\end{array}$ & $\begin{array}{c}\text { All } \\
\text { Transition }\end{array}$ & $\begin{array}{l}\text { Competitive, } \\
\text { Transition }\end{array}$ & $\begin{array}{l}\text { Competitive, No } \\
\text { Transition }\end{array}$ & $\begin{array}{l}\text { Transition, } \\
\text { Uncompetitive }\end{array}$ \\
\hline & $\mathrm{FE}$ & $\mathrm{FE}$ & $\mathrm{FE}$ & $\mathrm{FE}$ & $\mathrm{FE}$ & Sys-GMM & Sys-GMM & Sys-GMM & Sys-GMM & Sys-GMM \\
\hline election_e5_comp & $\begin{array}{r}-0.0027 * * \\
(0.0011)\end{array}$ & & & & & $\begin{array}{c}-0.0042^{* * *} * \\
(0.0011)\end{array}$ & & & & \\
\hline election_e5_transition & & $\begin{array}{r}-0.0023^{*} \\
(0.0012)\end{array}$ & & & & & $\begin{array}{r}-0.0029 * * \\
(0.0014)\end{array}$ & & & \\
\hline election_e5_comp_trans & & & $\begin{array}{r}-0.0028^{* *} * \\
(0.0013)\end{array}$ & & & & & $\begin{array}{c}-0.0044 * * * \\
(0.0013)\end{array}$ & & \\
\hline election_e5_comp_notrans & & & & $\begin{array}{r}-0.0023 \\
(0.0017)\end{array}$ & & & & & $\begin{array}{r}-0.0034 * \\
(0.0019)\end{array}$ & \\
\hline election_e5_trans_nocomp & & & & & $\begin{array}{c}-0.0014 \\
(0.0022)\end{array}$ & & & & & $\begin{array}{c}-0.0002 \\
(0.0029)\end{array}$ \\
\hline $\operatorname{AR}(1)$ & & & & & & 0.000 & 0.000 & 0.000 & 0.000 & 0.000 \\
\hline $\operatorname{AR}(2)$ & & & & & & 0.343 & 0.350 & 0.345 & 0.334 & 0.346 \\
\hline Hansen & & & & & & 0.814 & 0.685 & 0.672 & 0.822 & 0.685 \\
\hline No. of obs. & 1,870 & 1,870 & 1,870 & 1,870 & 1,870 & 1,870 & 1,870 & 1,870 & 1,870 & 1,870 \\
\hline No. of countries & 98.000 & 98.000 & 98.000 & 98.000 & 98.000 & 98.000 & 98.000 & 98.000 & 98.000 & 98.000 \\
\hline $\mathrm{R}^{2}$ & 0.689 & 0.689 & 0.689 & 0.689 & 0.688 & & & & & \\
\hline
\end{tabular}

Notes: standard errors in parentheses. Fixed-effects results are calculated with robust standard errors. Sys-GMM results are based on the two-step SysGMM procedure with Windmeijer standard errors. The results reported here are based on a simple specification, with the LDV and elections variable treated as endogenous, the control variables treated as exogenous and a collapsed instrument matrix. The p-values reported for the Hansen statistic are for the null hypothesis that the instruments are valid. The values reported for AR(2) are p-values for tests of second-order autocorrelation. Estimates all include the standard set of controls - lgdp, agric, imports, civil_war, totnontax, inflation and growthpc - though they are not reported here to conserve space. ${ }^{*} \mathrm{p}<0.10, * * \mathrm{p}<0.05, * * * \mathrm{p}<0.01$. 
elections that are both competitive and involve the removal of the incumbent. This is consistent with pre-election declines in tax collection reflecting both a strategic government choice and reduced capacity; the latter poses a greater challenge where the incumbent is comparatively unpopular. That said, it is important to stress that conclusions related to mechanisms should be treated with some caution: we are employing only somewhat imperfect proxies for the concepts of interest, the differences between alternative subsets of competitive and transitional elections are not always themselves statistically significant, and the larger decline in tax collection prior to elections that are both competitive and transitional could reflect a greater willingness to adopt such measures among governments facing the greatest electoral threats.

\section{ROBUSTNESS CHECKS}

While the core results tell a relatively clear story, cross-country econometric results can prove very sensitive to choices about data, sample, variables, estimators and model specification. We thus implement an extensive range of robustness checks, with most of the tables presented in the Appendix due to space constraints. These checks confirm the broad robustness of the results and offer additional insights into particular features of the relationship between elections and tax collection.

While all of the results are robust to employing both fixed-effects and Sys-GMM, there may still be some concerns about sensitivity to the choice of estimator. The Sys-GMM estimator has been criticized for being sensitive to the details of model specification - and particularly to the definition of the instrument set. We thus test the robustness of the results to alternative specifications of the model, and confirm that the results are generally robust to both changes in the number of lags used as instruments and to changes in whether key variables are defined as exogenous or endogenous (Table A2 in the Appendix). There is also a potential concern that the very high Hansen statistics in some of the results may be misleading, and reflect the excessive proliferation of instruments. ${ }^{71}$ However, we confirm that this is not the case here. The high Hansen statistics reflect the decision to implement models involving two election terms, which allows us to formally test whether competitive elections have a statistically significantly and distinct impact on tax collection, compared to other multiparty elections. This expands the instrument set, and yields higher Hansen statistics. However, when we simplify the model to involve only the individual election term of interest the core message of the results remains unchanged, and the Hansen statistics drop into a more comfortable range. ${ }^{72}$ Finally, while the existing literature in this area almost universally relies on Sys-GMM and fixed-effects estimators, we further test the robustness of the results using a first-differences estimator. While this yields results that are slightly smaller in magnitude and significance, the overall pattern of significant results remains unchanged (Table A3).

We subsequently subject all of the results to a series of overarching robustness tests. Though not reported here in order to conserve space, all results were tested for alternative sets of control variables from the literature, including the share of the population under the age of fourteen, the share of the population over the age of sixty-five, the level of urbanization and region-specific dummy variables. The core results are entirely unchanged. It also seems possible that fiscal dynamics may be quite different in countries involved in IMF programs, which may, for

71 Roodman 2009.

72 Specifically, using competitive elections for illustration, $\operatorname{Tax}_{i, t}=\varphi$ Tax $_{i, t-l}+\beta_{1}$ Election_e5_comp $_{i, t}+$ $X_{i, t-1}^{\prime} \delta+\alpha_{i}+\lambda_{t}+e_{i, t}$. We also use this simplified specification for many of the robustness tests, either for simplicity or where reduced sample sizes make the Sys-GMM results appear more fragile. 
example, restrict the potential for reduced tax collection in election years. ${ }^{73}$ We correspondingly add a variable for membership in IMF programs, but find the results broadly unchanged. ${ }^{74}$

We also explore robustness to choices about data. All of the results are first replicated employing data exclusively at the central government level, whereas the core analysis employs the preferred version of the ICTD GRD dataset, which includes general government data where relevant for federal states. ${ }^{75}$ Conceptually, it is ambiguous whether it is more appropriate to employ central or general government data: elections are at the central government level, but often overlap with local elections, and may in any case affect local tax collection. Ultimately, the results again reinforce the core message, as the effect of competitive elections remains significant and of similar magnitude (Table A4). A related concern is that the results may be sensitive to the time period covered by the data being employed; therefore we run tests in which we progressively 'trim' the length of the sample both by imposing later start dates and earlier end dates. As expected, reducing the sample size weakens the significance of the results slightly; however, overall the results are notably robust even when cutting almost half of the total sample. Competitive elections continue to have a significant effect even when the time period is sharply limited to only 1998-2010, while their impact falls only slightly short of significance at conventional levels (and still with a large magnitude) when the time period is limited to 1980-1998 (Tables A5 and A6). ${ }^{76}$

An alternative concern is that the results may be driven by a particular definition of the 'effective' election year. In the core results we look for the fiscal effects of elections in the year prior to elections if the election occurs in the first five months of a given calendar year. However, this cut-off point is somewhat arbitrary, reflecting a best guess about how long prior to an election the fiscal effects of that election are likely to be felt. Tables $5 \mathrm{a}$ and $5 \mathrm{~b}$ correspondingly report summary results for the impact of competitive elections on pre-election tax collection when employing alternative definitions of the effective election year. The far left column reports the effects of an election on taxation strictly in the calendar year in which it occurred (election_e0). The columns moving to the right display the electoral effects in the preceding year if the election occurred in or before each of months 1 (election_e1) through 12 (election_e12), while the final columns report the fiscal effects of an election two calendar years in advance if the election occurred in the first month of the year. The tables offer insight into the length of time prior to an election during which the fiscal effects are felt; significant coefficients further to the right in the tables signal that declines in taxation occur further in advance of competitive elections.

Ultimately, the results are remarkably supportive of the conclusions drawn so far. Using both the Sys-GMM and fixed-effects estimators, the results prove very robust to changes in the definition of the effective election year: the results are significant and large for every value from election_e4 to election_e11. This suggests that election-motivated reductions in tax collection have tended to occur quite far in advance of elections - and somewhat further in advance of elections than election-driven increases in expenditure. ${ }^{77}$ As important, the results decline at the 'tails' of the tables, as the 'lag' length becomes too short or too long, precisely as we would expect. For elections that occur early in the calendar year, the results employing election_c

${ }^{73}$ See, for example, Mahon 2004.

${ }^{74}$ Results available on request.

${ }^{75}$ See description in Prichard, Cobham, and Goodall (2014).

76 This pattern of results may also reflect the importance of data quality: data are both less complete and of more uncertain quality during the earlier period, which may help explain the higher standard errors, lower significance levels and overall greater volatility of the results.

${ }_{77}$ Most existing studies of political budget cycles in developing countries have employed both the calendar year definition of effective election year and measures of election year ranging from $e 3$ to $e 6$ (e.g., Ehrhart 2013). 
TAB LE 5A Impact of Employing Alternative Definitions of Election Year - Fixed Effects, Competitive Elections

\begin{tabular}{|c|c|c|c|c|c|c|c|c|c|c|c|c|c|c|}
\hline & (1) & (2) & (3) & (4) & (5) & (6) & (7) & (8) & (9) & (10) & (11) & (12) & (13) & (14) \\
\hline & $\lambda=\mathrm{C}$ & $\lambda=\mathrm{E} 1$ & $\lambda=\mathrm{E} 2$ & $\lambda=\mathrm{E} 3$ & $\lambda=\mathrm{E} 4$ & $\lambda=\mathrm{E} 5$ & $\lambda=\mathrm{E} 6$ & $\lambda=\mathrm{E} 7$ & $\lambda=\mathrm{E} 8$ & $\lambda=\mathrm{E} 9$ & $\lambda=\mathrm{E} 10$ & $\lambda=\mathrm{E} 11$ & $\lambda=\mathrm{E} 12$ & $\lambda=\mathrm{E} 13$ \\
\hline & $\mathrm{FE}$ & $\mathrm{FE}$ & $\mathrm{FE}$ & $\mathrm{FE}$ & $\mathrm{FE}$ & $\mathrm{FE}$ & $\mathrm{FE}$ & $\mathrm{FE}$ & $\mathrm{FE}$ & $\mathrm{FE}$ & $\mathrm{FE}$ & $\mathrm{FE}$ & $\mathrm{FE}$ & $\mathrm{FE}$ \\
\hline election_ $\lambda \_$comp & $\begin{array}{c}-0.0004 \\
(0.0010)\end{array}$ & $\begin{array}{l}-0.0006 \\
(0.0011)\end{array}$ & $\begin{array}{l}-0.0005 \\
(0.0011)\end{array}$ & $\begin{array}{c}-0.0011 \\
(0.0012)\end{array}$ & $\begin{array}{r}-0.0027 * * \\
(0.0011)\end{array}$ & $\begin{array}{r}-0.0027^{* *} * \\
(0.0011)\end{array}$ & $\begin{array}{r}-0.0029 * * \\
(0.0011)\end{array}$ & $\begin{array}{r}-0.0030^{* *} \\
(0.0012)\end{array}$ & $\begin{array}{c}-0.0034^{* * *} * \\
(0.0012)\end{array}$ & $\begin{array}{c}-0.0034 * * * \\
(0.0012)\end{array}$ & $\begin{array}{r}-0.0028 * * \\
(0.0012)\end{array}$ & $\begin{array}{c}-0.0022 * \\
(0.0012)\end{array}$ & $\begin{array}{c}-0.0020 \\
(0.0013)\end{array}$ & $\begin{array}{r}-0.0004 \\
(0.0010\end{array}$ \\
\hline No. of obs. & 1,870 & 1,870 & 1,870 & 1,870 & 1,870 & 1,870 & 1,870 & 1,870 & 1,870 & 1,870 & 1,870 & 1,870 & 1,870 & 1,870 \\
\hline No. of countries & 98.000 & 98.000 & 98.000 & 98.000 & 98.000 & 98.000 & 98.000 & 98.000 & 98.000 & 98.000 & 98.000 & 98.000 & 98.000 & 98.000 \\
\hline $\mathrm{R}^{2}$ & 0.688 & 0.688 & 0.688 & 0.689 & 0.689 & 0.689 & 0.689 & 0.689 & 0.689 & 0.689 & 0.689 & 0.689 & 0.689 & 0.688 \\
\hline
\end{tabular}

Note: standard errors in parentheses. Results are calculated with robust standard errors. Control variables lgdp, agric, imports, civil_war, totnontax, inflation and growthpc are included in all regressions, but are not reported in order to conserve space. $* \mathrm{p}<0.10, * * \mathrm{p}<0.05, * * * \mathrm{p}<0.01$. 
T А В LE 5 в Impact of Employing Alternative Definitions of Election Year - System-GMM, Competitive Elections

\begin{tabular}{|c|c|c|c|c|c|c|c|c|c|c|c|c|c|c|}
\hline & (1) & (2) & (3) & (4) & (5) & (6) & (7) & (8) & (9) & (10) & (11) & (12) & (13) & (14) \\
\hline & $\lambda=\mathrm{C}$ & $\lambda=\mathrm{E} 1$ & $\lambda=\mathrm{E} 2$ & $\lambda=\mathrm{E} 3$ & $\lambda=\mathrm{E} 4$ & $\lambda=\mathrm{E} 5$ & $\lambda=\mathrm{E} 6$ & $\lambda=\mathrm{E} 7$ & $\lambda=\mathrm{E} 8$ & $\lambda=\mathrm{E} 9$ & $\lambda=\mathrm{E} 10$ & $\lambda=\mathrm{E} 11$ & $\lambda=\mathrm{E} 12$ & $\lambda=\mathrm{E} 13$ \\
\hline & Sys-GMM & Sys-GMM & Sys-GMM & Sys-GMM & Sys-GMM & Sys-GMM & Sys-GMM & Sys-GMM & Sys-GMM & Sys-GMM & Sys-GMM & Sys-GMM & Sys-GMM & Sys-GMM \\
\hline election_c_comp & $\begin{array}{c}-0.0006 \\
(0.0010)\end{array}$ & $\begin{array}{c}-0.0013 \\
(0.0013)\end{array}$ & $\begin{array}{c}-0.0013 \\
(0.0012)\end{array}$ & $\begin{array}{c}-0.0020 \\
(0.0013)\end{array}$ & $\begin{array}{c}-0.0036 * * * \\
(0.0011)\end{array}$ & $\begin{array}{c}-0.0042^{* * * *} \\
(0.0011)\end{array}$ & $\begin{array}{c}-0.0043 * * * \\
(0.0011)\end{array}$ & $\begin{array}{c}-0.0042^{* * * *} \\
(0.0012)\end{array}$ & $\begin{array}{c}-0.0045 * * * \\
(0.0012)\end{array}$ & $\begin{array}{c}-0.0046^{* * *} * \\
(0.0012)\end{array}$ & $\begin{array}{c}-0.0035 * * * \\
(0.0013)\end{array}$ & $\begin{array}{c}-0.0026 * * * * \\
(0.0010)\end{array}$ & $\begin{array}{r}-0.0021 * * \\
(0.0010)\end{array}$ & $\begin{array}{c}-0.0007 \\
(0.0010)\end{array}$ \\
\hline No. of obs. & 1,870 & 1,870 & 1,870 & 1,870 & 1,870 & 1,870 & 1,870 & 1,870 & 1,870 & 1,870 & 1,870 & 1,870 & 1,870 & 1,870 \\
\hline No. of countries & 98.000 & 98.000 & 98.000 & 98.000 & 98.000 & 98.000 & 98.000 & 98.000 & 98.000 & 98.000 & 98.000 & 98.000 & 98.000 & 98.000 \\
\hline
\end{tabular}

Note: standard errors in parentheses. All results are based on the two-step Sys-GMM procedure with Windmeijer standard errors. The p-values reported for the Hansen statistic are for the null hypothesis that instruments are valid. The values reported for AR(2) are p-values for tests of second-order autocorrelation. Control variables lgdp, agric, imports, civil_war, totnontax, inflation and growthpc are included in all regressions, but are not reported in order to conserve space. $* \mathrm{p}<0.10, * * \mathrm{p}<0.05, * * * \mathrm{p}<0.01$. 
capture primarily post-election patterns of tax collection, and ignore fiscal effects that occur in the calendar year prior to the election. Meanwhile, as the lag becomes too long - particularly when we look two calendar years prior to the election using election_e13 - the results are capturing fiscal dynamics so far in advance of the election that we should not yet expect to see election-motivated reductions in taxation. That the results so closely track theoretical expectations - while also proving robust to a wide range of definitions of election year provides substantial confidence in the results. ${ }^{78}$

In order to further deepen the analysis, we perform a similar analysis examining the impact of transition elections (election_transition), competitive and transition elections (election_comp_trans), competitive elections without a transition (election_comp_notrans) and transitional elections that are not competitive (election_trans_nocomp). The results - reported in Appendix Tables A7-A14 offer further support for the core results, while suggesting again that the decline in tax collection in competitive election years is attributable primarily to government strategy, but also in part to weakened capacity in the face of popular resistance.

As in the earlier results, we find a generally negative and significant coefficient on transition elections, but this is only true with a longer lag length. This is consistent with the story told so far. With a short lag length we are capturing primarily post-election tax collection for elections held early in the year, and the lack of significance with a short lag length suggests a significant recovery of tax collection following transitional elections. This is, in turn, consistent with capacity playing an important role in pre-election declines in tax collection: the recovery of tax collection after transitions is consistent with reduced public opposition and improved administrative effort following the election of a more popular government. Meanwhile, we again find evidence that the largest and most significant declines in tax collection occur prior to elections that are both competitive and involve replacing the incumbent, which is consistent with the decline being driven by both government strategy and diminished capacity. By contrast, the decline in taxation prior to competitive elections in which the incumbent is returned to power is infrequently significant, while uncompetitive elections in which the incumbent is replaced are rarely significant. ${ }^{79}$ That said, these results should again be treated with some caution, and are best understood as being indicative of the underlying mechanisms, but not as definitive proof.

The final set of robustness checks focuses on the sensitivity of the results to changes in the sample. We report core results for: all countries, all non-resource-dependent countries, all nonresource dependent developing countries and low-income countries exclusively. The results are all broadly consistent with those reported so far. When developed countries are included in the sample (Tables A21-A24), competitive elections remain significant, but the magnitude and significance of the effect declines somewhat despite the larger sample size, which is consistent with political budget cycles being less pronounced in OECD countries. ${ }^{80}$ When focusing exclusively on developing countries, but excluding major natural resource producers (Table A25-A26), the results are almost identical using the System-GMM estimator, and fall just short of significance using fixed effects. When we focus exclusively on low- and lower-middle income countries the impact of competitive elections again falls marginally short of significance at conventional levels using both estimators (Tables A27-A28). That said, the change

${ }^{78}$ This is, to our knowledge, the first study to explore sensitivity to alternative definitions of election year at this level of detail, at least within published results.

${ }^{79}$ Full sets of results for a subset of these definitions of effective election year are also included in Appendix Tables A15-A20. The tables employ the Sys-GMM estimator, but the results are broadly unchanged using fixed effects.

${ }^{80}$ de Haan and Klomp 2013. 
in the results is modest in all cases: the magnitude of the coefficients is always comparable to earlier findings, with any loss of significance primarily reflecting larger standard errors with a reduced sample size. ${ }^{81}$ Finally, following the literature, it may be that the effects we are uncovering are particularly strong in younger democracies, where checks and balances may be weak, and where citizens inexperienced with democracy may be more vulnerable to being influenced by short-term policy shifts. Consistent with this possibility, we find that the results are concentrated primarily in democracies that have existed for 10 years or less (Table A29). ${ }^{82}$

The only results that raise potential concerns are those indicating a marginal loss of significance when limiting the sample to lower-income countries. However, further investigation suggests that this should not be viewed as a significant challenge to the overall results. First, if we adopt a more restrictive definition of competitiveness, in which the government receives less than 50 per cent of total seats (election_e5_comp50), the results return to strong statistical significance, across multiple potential definitions of the effective election year (Table A30). ${ }^{83}$ Likewise, when we adopt alternative definitions of the effective election year, we find that the results are also statistically significant for our standard measure of competitiveness when looking for fiscal effects slightly longer before elections (Table A31). ${ }^{84}$

Finally, we conduct a more general set of particularly demanding tests to ensure that the results are not driven by a very small number of observations. We re-run the core results for competitive elections when systematically excluding the most extreme values - that is, the competitive elections that witnessed the largest election year decreases and increases in tax collection. Table A32 reports the results when we drop, respectively, roughly 10 per cent and 25 per cent of the sample, considering both of our two primary measures of competitiveness (election_comp and election_comp50) and two alternative definitions of election year. ${ }^{85}$ While the results predictably lose some explanatory power when systematically excluding influential observations, they nonetheless prove robust even to this particularly demanding test: the overall effect of competitive elections is significant at conventional levels in all but two specifications, while in both remaining cases the results are significant at the 11 per cent level.

While the results for competitive elections are thus very robust overall, the magnitude of the effect does decline somewhat when influential results are excluded. To explore the sources of this sensitivity, we focus more qualitative attention on countries in which tax collection increased or decreased particularly significantly prior to competitive elections (and which are excluded from the results in Table A32). Table 6 correspondingly lists those countries and competitive election years in which tax collection increased or decreased by, in turn, greater than 2 per cent of GDP, and 1.5-2.0 per cent of GDP. The broad characteristics of these cases - and particularly of those that experienced the largest election year changes in tax collection - appear to reinforce key elements of the story so far. Among countries that witnessed the largest election year declines in tax collection, many experienced a significant collapse in

\footnotetext{
81 Moreover, when a more restrictive definition of competitiveness (which includes only elections in which the government receives less than 50 per cent of total seats) is adopted, the coefficient on competitive elections almost doubles in magnitude, as in the earlier results.

${ }^{82}$ These young democracies were home to ninety-two of 161 competitive elections in the sample.

83 Results available on request.

84 The reported results focus on the fixed-effects estimator, as the diagnostic statistics for the Sys-GMM estimates become more suspect with the smaller sample size.

${ }^{85}$ More specifically, we first exclude any country that experienced an election year change in tax collection of at least 2 per cent of GDP, and then exclude any country that experienced a change of at least 1.5 per cent of GDP. In both cases, this implies dropping more countries that experienced decreases than that experienced increases, and is thus inherently expected to weaken the results.
} 


\section{Tax collection decreased by at least $2 \%$ prior to the election}

Belarus 2005

Mauritania 2006

Moldova 2009

Nicaragua 1989

Peru 1989

Romania 2000

Ukraine 2004

Tax collection decreased by $1.5-2 \%$ prior to the election

Argentina 1988
Costa Rica 2009
Dominican Republic 2003
El Salvador 1988
Honduras 2009
Madagascar 2001
Malawi 1993
Mozambique 1994
Ukraine 1999
Ukraine 2009

Tax collection increased by at least $2 \%$ prior to the election

Bosnia and Herzegovina 2006

Dem. Rep. Congo 2006

Lebanon 1996

Malawi 2003

Tax collection increased by $1.5-2 \%$ prior to the election

\author{
Azerbaijan 1998 \\ Colombia 2001 \\ Ecuador 2008 \\ Ghana 2000 \\ Lebanon 1996 \\ Madagascar 1992 \\ Papua New Guinea 1997
}

Note: the year listed next to each country is the 'effective' election year as coded in the data, which is sometimes one calendar year prior to the election.

Source: authors' calculations.

popular confidence in the government, a decline in administrative capacity and/or the weakening of the governing coalition. ${ }^{86}$ This is consistent with the argument that declining tax collection prior to elections in developing countries appears to reflect both government strategy and declining capacity where governments are deeply unpopular, with the latter particularly important in extreme cases. It is also consistent with pre-electoral declines in tax collection often being driven by changes in enforcement rather than policy, as in none of these cases do there appear to have been major downward changes in tax rates. Meanwhile, a look at those countries that experienced particularly large increases in tax collection prior to a competitive election is also instructive. While again exhibiting important variety, many such countries were recovering from crisis and/or pursuing pre-existing and ambitious tax reform programs. This is consistent with large tax increases prior to elections generally reflecting separate and preexisting pressures to increase revenue, unrelated to the election.

\section{DISCUSSION}

The initial goal of this article was to provide the most detailed existing exploration of political budget cycles affecting tax collection in developing countries. This effort has yielded novel

\footnotetext{
86 These countries have sometimes also often experienced economic crisis, but this is controlled for in the regression results.
} 
findings. Unlike recent results, ${ }^{87}$ the article finds no consistent and statistically significant evidence that elections in general - even when focusing exclusively on multiparty elections or free and fair elections - have led to reduced tax collection in election years. There is similarly no consistent evidence that elections have disproportionately affected indirect (or direct) taxes.

Instead, the results here offer evidence that political budget cycles affecting taxation are critically dependent on the extent to which elections are meaningfully competitive: tax collection declines an average of $0.3-0.5$ per cent of GDP prior to competitive elections. The consistency of this result across a range of robustness tests is, in turn, particularly compelling. The negative relationship becomes stronger as the definition of competitiveness becomes more restrictive, and weaker as it is relaxed, in line with theoretical expectations. The pattern of results as we alter the definition of the effective election year is equally striking: the results grow stronger as the lag between fiscal effects and elections is increased to the levels predicted by theory, and weaker as the lag becomes so long that it fails to capture the short-term effects of elections on taxation. Meanwhile, the results prove robust to changes in control variables, econometric approach, the choice of data, time period and the composition of the sample.

In turn, the results offer preliminary, though imperfect, insight into the causal mechanisms shaping pre-election declines in tax collection. Most discussion of political budget cycles implicitly or explicitly assumes that they result from strategic decisions by those in power to pursue short-term changes in fiscal policy. However, our results suggest that this may describe changes in expenditure much more effectively than changes in taxation.

Most basically, examination of the most influential cases here, coupled with case study evidence elsewhere, suggests that declines in taxation prior to elections have often not involved major policy changes, but have instead involved more informal changes in the effectiveness of tax enforcement and collection. This reliance on informality raises a question of credible commitment: Is it reasonable to believe that voters would be swayed by such obviously shortterm measures, and thus that politicians would adopt them? While not the primary focus here, there seem to be several possible explanations. Politicians themselves may overestimate the effectiveness of these measures, ${ }^{88}$ or voters may be very short-sighted or willing to be swayed by even short-term benefits. ${ }^{89}$ Both possibilities are consistent with the fact that political budget cycles affecting taxation appear to be centered in relatively young democracies. A third possibility is that some declines in taxation may not be entirely under the control of governments.

Building on the last possibility, the results here have sought to distinguish between two possible drivers of declines in taxation: strategic choices by governments seeking public support and reduced capacity for collection prior to elections among increasingly unpopular governments. While available data do not allow for precise tests of these alternatives, all of the data and tests conducted here are consistent with declines in taxation being driven by a combination of both factors. Most notably, taxation appears to have declined most significantly prior to elections that have been competitive and in which the incumbent has been particularly unpopular or weak, as reflected in an eventual electoral loss. These results need to be treated with caution, given the limits of the data and the difficulty of drawing airtight distinctions econometrically. However, these findings, which are consistent with recent case-based

\footnotetext{
87 Ehrhart 2013.

88 Illustratively, Prichard (2015) discusses reductions in taxation prior to elections in Ethiopia in 2005, which were widespread, but also widely viewed by the opposition as having been a relatively ineffective policy tool.

89 The literature on vote buying around African elections, for example, suggests that short-term giveaways may nonetheless influence outcomes (e.g., Vicente and Wantchekon 2009).
} 
research, ${ }^{90}$ imply a significantly different understanding of pre-election tax dynamics and new directions for research on political budget cycles affecting taxation.

While the results are thus important for understanding the dynamics of pre-election taxation, their significance lies at least equally in their implications for understanding broader political dynamics in developing countries. Most immediately, the results offer among the best existing evidence of the critical role of electoral competitiveness in conditioning the political incentives generated by developing country elections. Despite the centrality of electoral competitiveness to democratic theory, the importance of electoral competitiveness in developing countries has been surprisingly little studied. ${ }^{91}$ In a recent review of the literature on conditional budget cycles by de Haan and Klomp, ${ }^{92}$ the role of electoral competitiveness is mentioned only in a brief footnote. Even within developed countries only a handful of studies of political budget cycles have considered the importance of the margin of victory in conditioning the effects of elections; their results mirror those reported here. ${ }^{93}$

More broadly, recent quantitative studies of the effects of elections in developing countries have often continued to ask how multiparty elections in general affect development outcomes limited (or no) explicit attention is paid to the substantive competitiveness of those elections. ${ }^{94}$ While Block, Ferree and Singh have previously reported evidence that political budget cycles in developing countries are larger when elections are competitive, they defined competitiveness simply as the existence of multiparty competition, as their study predated the ready availability of high-quality data on electoral margins of victory. ${ }^{95}$ The results here suggest that such a minimalist definition of competition is inadequate. It is only when the opposition has posed a meaningful electoral threat that incumbent governments have been driven to offer tax reductions in an effort to secure electoral support. In a similar vein, there has been significant academic and policy attention to the importance of free and fair elections. Chauvet and Collier ${ }^{96}$ and Collier and Hoeffler, ${ }^{97}$ for example, have argued that the impact of elections on economic policy and growth is dependent on elections being high quality, which they define as requiring multiparty competition and the absence of widespread electoral malfeasance. Our results suggest that electoral competitiveness, rather than simply being free and fair, may be critical to the incentives generated by elections - though free and fair elections are themselves more likely to be competitive. This is intuitive: an election that is free and fair, but in which the opposition is extremely weak, seems less likely to substantially shape political leaders' incentives.

Of course, while the results here provide clear-cut evidence of the impact of electoral competitiveness on political incentives, they are capturing the impact of electoral competitiveness on short-term political incentives, rather than on long-term outcomes. Likewise, the short-term reductions in tax collection that are the focus here may frequently be a negative outcome from a social perspective. However, neither fact seems to undermine the broader conclusion. If competitive elections have a greater effect on short-term political incentives, there is every reason to believe that the same will be true of longer-term political incentives. Meanwhile, focusing on a relatively straightforward and immediate set of outcomes avoids many of the challenges of definition and attribution inherent in trying to link elections to

90 Prichard 2015.

91 Rakner and van de Walle 2009.

92 de Haan and Klomp 2013, 338.

93 Aidt, Veiga, and Veiga 2011; Efthyvoulou 2012.

${ }_{94}$ Harding and Stasavage 2014; Stasavage 2005.

95 Block, Ferree, and Singh 2003.

96 Chauvet and Collier 2009.

97 Collier and Hoeffler 2015. 
broader, more long-term, outcomes. ${ }^{98}$ It is entirely possible - and perhaps likely - that elections that place greater pressure on political leaders may generate short-term policy distortions, but larger longer-term gains in accountability. ${ }^{99}$

While the results thus have important implications for understanding the political incentives generated by developing country elections, they also represent an important contribution to the burgeoning literature on tax bargaining and accountability. This literature explores the possibility that countries that are more reliant on tax revenues are more likely to be accountable to citizens, owing to the need to bargain with citizens over the collection and use of tax revenue. Conventionally, research in this area has looked for evidence of comparatively explicit bargaining between citizens and governments, in which governments make governing concessions to taxpayers in order to encourage quasi-voluntary tax compliance and respond to taxpayer demands. ${ }^{100}$

However, Prichard ${ }^{101}$ has recently argued that tax bargaining may often take much more indirect forms, which are characterized not by compromises between citizens and governments but by unresolved fiscal conflicts with longer-term political consequences. For example, he cites processes of what he terms 'tax resistance and changes in government', by which citizens resist taxation by unpopular governments through evasion, avoidance and protest, thus reducing the state's fiscal capacity and increasing the likelihood of changes in government. He argues that this is a comparatively invisible means by which citizens may exercise power over unpopular governments. His argument emerges from detailed case studies, but yields a clear empirical prediction for cross-country research: that tax collection will decline faster prior to elections in which governments are unpopular, as popular resistance undermines government capacity for tax collection. This is precisely what is revealed by the results reported here, which thus offer the first significant econometric support for this form of indirect tax bargaining, and a lens into a heretofore largely overlooked dimension of political contestation in developing countries.

\section{CONCLUSIONS}

Narrowly, the contribution of this article lies in its insights about the effect of political budget cycles on taxation - a topic that has been comparatively overlooked, but which is particularly interesting owing to the potentially high costs to governments of reduced tax collection prior to elections. In significant part because of these high costs, the more ambitious contribution of the article lies in revealing broader lessons about the functioning of politics in developing countries. The first lesson is that electoral competitiveness has been critical in shaping the political incentives generated by elections, and, by extension, that the importance of electoral competitiveness in shaping the impact of democracy in developing countries warrants much greater attention. The second lesson is that changes in taxation are often not merely a reflection of government policy, but also of popular attitudes toward government. Consistent with recent

${ }^{98}$ For example, Chauvet and Collier (2009) employ potentially contentious and subjective measures of policy quality as their dependent variable, while Collier and Hoeffler (2015) measure the quality of economic governance by focusing on whether economic growth is higher or lower than regional averages. In both cases these indicators are open to question, and the causal chain linking elections to these outcomes is considerably more complex, thus making the results more uncertain.

${ }^{99}$ Chauvet and Collier 2009. Jibao and Prichard have presented precisely such evidence at the local government level in Sierra Leone, showing that competitive elections have resulted in both short-term declines in local government tax collection and long-term incentives for revenue-enhancing tax reform and broader governance improvements.

${ }^{100}$ See, for example, Ross 2004 and Moore 2008.

101 Prichard 2015. 
research, this suggests that resistance to taxation may be a potentially important, but often overlooked, form of political contestation, and an important aspect of understanding the potential links between taxation and broader political accountability.

\section{REFERENCES}

Aidt, Toke, Francisco Veiga, and Linda Veiga. 2011. Election Results and Opportunistic Policies: A New Test of the Rational Political Business Cycle Model. Public Choice 148:21-44.

Ascher, William. 1989. Risk, Politics and Tax Reform: Lessons From Some Latin American Experiences. In Tax Reform in Developing Countries, edited by Malcolm Gillis, 417-73. Durham, NC: Duke University Press.

Ayee, Joseph. 2011. Political Economy of the Mining Sector in Ghana, World Bank Policy Research Working Paper 5730. Washington, DC: World Bank.

Bates, Robert. 1989. A Political Scientist Looks at Tax Reform. In Tax Reform in Developing Countries, edited by Malcolm Gillis, 473-92. Durham, NC: Duke University Press.

Beck, Thorsten, George Clarke, Alberto Groff, Philip Keefer, and Patrick Walsh. 2001. New Tools in Comparative Political Economy: The Database of Political Institutions. World Bank Economic Review 15 (1):165-76.

Benedek, Dora, Ernesto Crivelli, Sanjeev Gupta, and Priscilla Muthoora. 2012. Foreign Aid and Revenue: Still A Crowding Out Effect? Working Paper 12/186. Washington, DC: IMF.

Bird, Richard, and Eric Zolt. 2005. Redistribution Via Taxation: The Limited Role of the Personal Income Tax in Developing Countries. International Tax Program Paper 0508. Toronto: Joseph L. Rotman School of Management.

Bishop, Sylvia, and Anke Hoefler. 2014. Free and Fair Elections - A New Database. CSAE Working Paper WPS/2014-14, Centre for the Study of African Economies, Oxford University.

Block, Steven A. 2002. Political Business Cycles, Democratization and Economic Reform: The Case of Africa. Journal of Development Economics 67 (2):205-28.

Block, Steven A., Karen Ferree, and Smita Singh. 2003. Multiparty Competition, Founding Elections and Political Business Cycles in Africa. Journal of African Economies 12 (3):444-68.

Blundell, Richard, and Stephen Bond. 1998. Initial Conditions and Moment Restrictions in Dynamic Panel Data Models. Journal of Econometrics 87 (1):115-43.

Bornhorst, Fabian, Sanjeev Gupta, and John Thornton. 2008. Natural Resource Endowments, Governance and the Domestic Revenue Effort: Evidence From a Panel of Countries. Working Paper Wp/08/170. Washington, DC: International Monetary Fund.

Brautigam, Deborah, Odd-Helge Fjeldstad, and Mick Moore, eds. 2008. Taxation and State-Building in Developing Countries: Capacity and Consent. Cambridge: Cambridge University Press.

Brender, Adi, and Allan Drazen. 2005. Political Budget Cycles in New Versus Established Democracies. Journal of Monetary Economics 52:1271-295.

Chauvet, Lisa, and Paul Collier. 2009. Elections and Economic Policy in Developing Countries. Economic Policy 24:509-50.

Collier, Paul, and Anke Hoeffler. 2015. Do Elections Matter for Economic Performance. Oxford Bulletin of Economics and Statistics 77:1-21.

de Haan, Jakob, and Jeroen Klomp. 2013. Conditional Political Budget Cycles: A Review of Recent Evidence. Public Choice 157:387-410.

Drazen, Allan. 2001. The Political Business Cycles After 25 Years. In NBER Macroeconomics Annals, edited by Ben Bernanke and Kenneth Rogoff, 75-117. Cambridge, MA: MIT Press.

Drazen, Allab, and Marcela Eslava. 2010. Electoral Manipulation Via Voter-Friendly Spending: Theory and Evidence. Journal of Development Economics 92 (1):39-52.

Efthyvoulou, Georgios. 2012. Political Budget Cycles in the European Union and the Impact of Political Pressures. Public Choice 153:295-327.

Ehrhart, Helene. 2013. Elections and the Structure of Taxation in Developing Countries. Public Choice 156 (2):195-211. 
Fjeldstad, Odd-Helge, and Colette Schulz-Herzenberg. 2012. Peoples' Views of Taxation in Africa: A Review of Research on Determinants of Tax Compliance, ICTD Working Paper 8. Brighton: International Center for Tax and Development.

Fjeldstad, Odd-Helge, and Ole Therkildsen. 2008. Mass Taxation and State-Society Relations in East Africa. In Taxation and State Building in Developing Countries: Capacity and Consent, edited by Deborah Brautigam, Odd-Helge Fjeldstad and Mick Moore, 114-35. Cambridge: Cambridge University Press.

Giliomee, Hermann, and Charles Simkins. 1999. The Awkward Embrace: One-Party Domination and Democracy. Amsterdam: Harwood Academic Publishers.

Gordon, Sanford, and Gregory Huber. 2007. The Effect of Electoral Competitiveness on Incumbent Behavior. Quarterly Journal of Political Science 2 (2):107-38.

Harding, Robin, and David Stasavage. 2014. What Democracy Does (and Doesn't Do) for Basic Services: School Fees, School Inputs and African Elections. The Journal of Politics 76 (1):229-45.

Hassan, Mirza, and Wilson Prichard. 2013. The Political Economy of Tax Reform in Bangladesh: Political Settlements, Informal Institutions and the Negotiation of Reform. IDS Working Paper 14. Brighton: Institute of Development Studies.

Herrera, Yoshiko, and Devesh Kapur. 2007. Improving Data Quality: Actors, Incentives and Capabilities. Political Analysis 15:365-86.

Hyde, Susan D., and Nikolay Marinov. 2012. Which Elections Can Be Lost? Political Analysis 20 (2): $191-210$.

International Monetary Fund (IMF), Article IV Staff Reports. Washington, DC: IMF.

International Monetary Fund (IMF), Government Finance Statistics. Washington, DC: IMF.

Jerven, Morten. 2013. Poor Numbers: How We Are Misled by African Development Statistics and What To Do About It. Ithaca, NY: Cornell University Press.

Jibao, Samuel, and Wilson Prichard. 2013. Rebuilding Local Government Finances After Conflict: The Political Economy of Property Taxation in Post-Conflict Sierra Leone ICTD Working Paper 12. Brighton: International Centre for Tax and Development.

Joshi, Anuradha, Wilson Prichard, and Christopher Heady. 2014. Taxing the Informal Economy: The Current State of Knowledge and Agendas for Future Research. Journal of Development Studies. 50 (10):1325-347.

Keen, Michael, and Mario Mansour. 2009. Revenue Mobilization in Sub-Saharan Africa: Challenges From Globalization IMF Working Paper 09/157. Washington, DC: International Monetary Fund.

Kelley, Judith, and Kiril Kolev. 2010. Election Quality and International Observation 1975-2004: Two New Datasets. Durham, NC: Duke University.

Kitschelt, Herbert, and Steven Wilkinson. 2007. Citizen-Politician Linkages: An Introduction. In Patrons, Clients and Policies: Patterns of Democratic Accountability and Political Competition, edited by Herbert Kitschelt and Steven Wilkinson, 1-30. Cambridge: Cambridge University Press.

Mahon, James. 2004. Causes of Tax Reform in Latin America, 1977-95. Latin American Research Review 39:4-31.

Marshall, Monty, Keith Jaggers, and Ted Robert Gurr. 2012. Political Regime Characteristics and Transitions, 1800-2008. Polity IV Project. Vienna, VA: Center for Systemic Peace.

Martin, Isaac, and Nadav Gabay. 2007. Do Visible Taxes Cause Protest? Tax Policy and Tax Protest in Rich Democracies. La Jolla, CA: Department of Sociology, University of California-San Diego.

Moore, Mick. 2008. Between Coercion and Contract: Competing Narratives on Taxation and Governance. In Taxation and State Building in Developing Countries: Capacity and Consent, edited by Deborah Brautigam, Odd-Helge Fjeldstad and Mick Moore, 34-63. Cambridge: Cambridge University Press. Nickell, Stephen. 1981. Biases in Dynamic Models With Fixed Effects. Econometrica 49:1417-426.

Norhaus, William. 1975. The Political Business Cycle. Review of Economic Studies 42:169-90.

Osei, Philip D. 2000. Political Liberalisation and the Implementation of Value Added Tax in Ghana. Journal of Modern African Studies 38 (2):255-78.

Persson, Torsten, and Guido Tabellini. 2002. Do Electoral Cycles Differ Across Political Systems?. Stockholm: IIES, Stockholm University. 
Prichard, Wilson. 2015. Taxation, Responsiveness and Accountability in Sub-Saharan Africa: The Dynamics of Tax Bargaining. Cambridge: Cambridge University Press.

Prichard, Wilson, Alex Cobham, and Andrew Goodall. 2014. The ICTD Government Revenue Dataset, ICTD Working Paper 19. Brighton: International Centre for Tax and Development.

Rakner, Lise, and Nicolas van de Walle. 2009. Opposition Weakness in Africa. Journal of Democracy 20:108-21.

Rogoff, Kenneth. 1990. Equilibrium Political Budget Cycles. American Economic Review 80 (1):21-36.

Rogoff, Kenneth, and Anne Sibert. 1988. Elections and Macroeconomic Policy Cycles. Review of Economic Studies 55 (1):1-16.

Roodman, David. 2006. How to Do xtabond2: An Introduction to 'Difference' and 'System' GMM. Stata Center for Global Development Working Paper Number 103. Washington, DC: Center for Global Development.

Roodman, David. 2009. A Note on the Theme of Too Many Instruments. Oxford Bulletin of Economics and Statistics 71 (1):135-58.

Ross, Michael. 2004. Does Taxation Lead to Representation? British Journal of Political Science 34: 229-49.

Schedler, Andreas. 2002. The Menu of Manipulation. Journal of Democracy 13:37-50.

Schuknecht, Ludger. 2000. Fiscal Policy Cycles and Public Expenditure in Developing Countries. Public Choice 102:115-30.

Shi, Min, and Jakob Svensson. 2006. Political Budget Cycles: Do They Differ Across Countries and Why? Journal of Public Economics 90:1367-89.

Stasavage, David. 2005. Democracy and Education Spending in Africa. American Journal of Political Science 49 (2):343-58.

Tendler, Judith. 2002. Small Firms, the Informal Sector and the Devil's Deal. IDS Bulletin 33 (3):1-15.

Themnér, Lotta, and Peter Wallensteen. 2014. Armed Conflict, 1946-2013. Journal of Peace Research 51 (4):541-54.

Therkildsen, Ole. 2012. Democratisation in Tanzania: No Taxation Without Exemptions. Paper Presented at the Annual Meeting of the American Political Science Association, New Orleans, LA. 30 August to 2 September 2012 .

Timmons, Jeffrey F. 2010. Taxation and Representation in Recent History. The Journal of Politics 72 (1):191-208.

van de Walle, Nicolas. 2003. Presidentialism and Clientelism in Africa's Emerging Party Systems. The Journal of Modern African Studies 41 (2):297-321.

Vicente, Pedro, and Leonard Wantchekon. 2009. Clientelism and Vote Buying: Lessons From Field Experiments in African Elections. Oxford Review of Economic Policy 25 (2):292-305.

World Bank, World Development Indicators dataset. Available at http://data.worldbank.org/data-catalog/ world-development-indicators. 